IZA DP No. 482

\title{
Leadership Skills and Wages
}

\author{
Peter Kuhn \\ Catherine Weinberger
}

April 2002 


\title{
Leadership Skills and Wages
}

\author{
Peter Kuhn \\ University of California, Santa Barbara \\ and IZA, Bonn \\ Catherine Weinberger \\ University of California, Santa Barbara \\ Discussion Paper No. 482 \\ April 2002 \\ IZA \\ P.O. Box 7240 \\ D-53072 Bonn \\ Germany \\ Tel.: +49-228-3894-0 \\ Fax: +49-228-3894-210 \\ Email: iza@iza.org
}

This Discussion Paper is issued within the framework of IZA's research area Evaluation of Labor Market Policies and Projects. Any opinions expressed here are those of the author(s) and not those of the institute. Research disseminated by IZA may include views on policy, but the institute itself takes no institutional policy positions.

The Institute for the Study of Labor (IZA) in Bonn is a local and virtual international research center and a place of communication between science, politics and business. IZA is an independent, nonprofit limited liability company (Gesellschaft mit beschränkter Haftung) supported by the Deutsche Post AG. The center is associated with the University of Bonn and offers a stimulating research environment through its research networks, research support, and visitors and doctoral programs. IZA engages in (i) original and internationally competitive research in all fields of labor economics, (ii) development of policy concepts, and (iii) dissemination of research results and concepts to the interested public. The current research program deals with (1) mobility and flexibility of labor, (2) internationalization of labor markets, (3) welfare state and labor markets, (4) labor markets in transition countries, (5) the future of labor, (6) evaluation of labor market policies and projects and (7) general labor economics.

IZA Discussion Papers often represent preliminary work and are circulated to encourage discussion. Citation of such a paper should account for its provisional character. A revised version may be available on the IZA website (www.iza.org) or directly from the author. 
IZA Discussion Paper No. 482

April 2002

\section{ABSTRACT}

\section{Leadership Skills and Wages*}

American business seems to be infatuated with its workers' "leadership" skills. Is there such a thing, and is it rewarded in labor markets? Using the Project Talent, NLS72 and High School and Beyond datasets, we show that men who occupied leadership positions in high school earn more as adults, even when cognitive skills are held constant. The pure leadership-wage effect varies from four percent for a broad definition of leadership in 1971 to twenty-four percent for a narrow definition in 1992, and appears to have increased over time. High-school leaders are more likely to occupy managerial occupations as adults, and leadership skills command a higher wage premium within managerial occupations than other jobs. We find evidence that leadership skill has a component that is determined before high school, but also find evidence that it is "teachable".

JEL Classification: $\quad$ I21, J24, J31

Keywords: education, leadership, wages, ability

Peter Kuhn

Department of Economics

University of California, Santa Barbara

Santa Barbara, CA 93106-9210

Tel.: +1 (805) 893-3666

Fax: +1 (805) 893-8830

Email: pjkuhn@econ.ucsb.edu

\footnotetext{
* We thank the Institute for Social, Behavioral and Economic Research at UC Santa Barbara and the Spencer Foundation for research support. Simon Chapple, Christopher Jencks, Michael Ornstein, and James Rosenbaum provided helpful comments. Chau Do provided excellent research assistance.
} 


\section{Introduction.}

Today's businesses, workers and educational institutions seem to be infatuated with a personal characteristic called "leadership". A recent search of books in print yielded over 5000 titles containing the word "leadership", the vast majority of which were training or self-help manuals aimed at a business or non-profit audience. ${ }^{-}$Leadership training courses and institutes are proliferating, with some firms paying large sums to send their workers. ${ }^{2}$ The Leadership Quarterly has been publishing academic articles on the development and measurement of leadership since 1990. A recent Time Magazine article lists high school leadership as one of the primary characteristics sought by admissions officers at elite universities (Morse, 2001). And top business schools, such as Wharton, send MBA students to Marine-run "boot camps" for the express reason of fostering leadership skills (Scannell, 2001).

Compared to the kinds of cognitive skills measured by tests like the AFQT --on which economists have focused almost exclusively in studies of earnings determination-- interpersonal skills including leadership rank much higher in the list of employee attributes employers say they seek in workers. For example, in a recent nationwide survey, the National Association of Colleges and Employers (NACE, 2000) found that employers' five most highly-valued personal qualities, in order, were communications skills, motivation/initiative, teamwork skills, leadership skills, and academic achievement/GPA. These were followed by interpersonal skills, flexibility/adaptability, technical skills, and honesty/integrity; with "work ethic" and analytical/problem-solving skills tied for tenth place. Only two of these eleven qualities

\footnotetext{
${ }^{1}$ June 11, 2001 at http://www.booksinprint.com/bip/. A random selection of recent titles includes: "The Most Effective Organization in the U. S.: Leadership Secrets of the Salvation Army"; "Jesus on Leadership: Executive Lessons from the Servant Leader"; "The 12 Rings of Leadership: Classic Lessons from J. R. R. Tolkein's 'The Hobbit' \& 'The Lord of the Rings"”; "Leadership Ensemble: Lessons in Collaborative Management from the World's Only Conductorless Orchestra"; "Take Command!: Leadership Lessons from the Civil War"; "Competitive Leadership: Twelve Principles for Success from a Super Bowl Winning Coach"; " Shakespeare on Management: Leadership Lessons for Managers"; "Moses on Leadership: How to Lead People With Purpose"; "The Dead Bison Theory: Other Secrets for Leadership in an Excessive Performance Organization", and "Shackleton's Way: Leadership Lessons from the Great Antarctic Explorer".

${ }^{2}$ For one of many examples, see the Center for Creative Leadership at http://www.ccl.org.
} 
(academic achievement and analytical/problem solving skills) seem to correspond somewhat closely to what is measured by the AFQT.

Is there such a thing as "leadership skill"? Can it be measured and distinguished from analytical or cognitive skills and from other forms of human capital such as education and experience, and is it rewarded in labor markets? To examine these issues, we use three data sets that are representative of the national population of high school students in 1960 (Project Talent), 1972 (NLS72), and 1982 (High School and Beyond). All three surveys include information on family background, scores from standardized cognitive tests taken in high school, and labor market outcomes approximately ten years after high school. All three include a "behavioral" measure of leadership taken during high school (acting as a team captain or club president) while two also contain other measures of leadership skill.

Our basic methodology regresses adult wages on indicators of leadership skills taken before labor market entry (i.e. in high school), controlling for standard measures of cognitive ability, family background, and (in some specifications) high school fixed effects. Our use of prelabor market measures of leadership skill allows us to avoid certain kinds of endogeneity, for example the possibility that individuals who do well in the labor market for some unrelated reason (e.g. a "lucky" promotion) might begin to develop those very leadership skills whose effects we wish to measure. ${ }^{\text {B }}$ The control for cognitive skills ensures that we are capturing only the additional effect of a "noncognitive" skill such as leadership. We conduct a variety of tests to determine whether leadership, as measured here, is in fact a distinct skill that is related to the management of people. These include examining interaction effects between leadership skills and other determinants of earnings, adding controls for other psychological characteristics for which leadership may be acting as a proxy, estimating the effect of leadership skills on

\footnotetext{
${ }^{3}$ Even more to the point, in wage regressions using concurrent self-assessed measures of leadership, accidentallysuccessful individuals might interpret their success as evidence of exceptional leadership ability.

4 The term "non-cognitive skills" seems to have arisen to distinguish personality measures or social skills from standard math and verbal skill measures, which have generally been referred to as "cognitive skills". Psychologists sometimes object to the term, rightly pointing out that cognition is involved in the use of these other skills as well.
} 
occupational assignment, and examining the functional form of the leadership-earnings relationship.

Our main results are as follows. First, controlling for family background, for all the standard measures of human capital, for all factors associated with the high school attended (via high-school fixed effects) and for mathematics test scores, individuals who exhibited leadership propensities in high school earn significantly more about ten years later. This effect is observed in all data sets and econometric specifications. Its size varies with the breadth of the leadership measure and across years, ranging from four percent for a broad definition of leadership in 1971 to 24 percent for a narrower definition in 1992. Second, only a quarter of the leadership effect on adult earnings operates through differences in educational attainment after high school. This, together with other results summarized below, suggests that our leadership measures are not acting as proxies for other personal attributes, such as persistence, a low discount rate, or measurement error in cognitive skills.

Third, the skill identified by this leadership measure is largely orthogonal to Herrnstein and Murray's (1994) concept of general intelligence, or " $g$ ", as measured by mathematics test scores. This provides some support to those psychologists (e.g. Gardner 1983; Sternberg, 1988) who advocate a multi-dimensional view of intelligence. Relatedly, the marginal effect of leadership skills on earnings does not vary with the respondent's level of education, or with the level of math scores, working just as strongly for low-math-score and low-education individuals as for others.

Fourth, the effect of leadership skills on earnings increases with experience, only beginning to emerge some 7 to 8 years after high school. Interestingly, this pattern mirrors the wage effects of high-school AFQT scores in Farber and Gibbons (1996). One interpretation suggested by Farber and Gibbons' model-- is that, even though leadership is readily measurable during high school, it takes time for the labor market to "learn" individuals' leadership abilities. Another is simply that leadership skills and experience are complementary factors of production: 
these leadership skills only begin to matter once one has acquired a certain amount of basic work knowledge and begins to take a more active hand in the organization and coordination of group efforts.

Fifth, as suggested by hierarchical models of production and job assignment such as Rosen (1982), our evidence suggests that labor market rewards are a convex function of leadership skills, generating especially high rewards for persons in the top tail of the leadership skill distribution. For example, in 1972, persons who had been in the top three percent of selfassessed leadership skills during high school eleven years earlier earned sixteen percent more than those in the bottom third of leadership skills in their high school -holding math scores, parental background and subsequent education constant. In 1991 the top three percent of leaders earned twenty-nine percent more than the bottom third.

Sixth, as suggested by the above comparison, the earnings effect of leadership skills appears to have increased substantially in magnitude between 1971 and 1992. The increase in the marginal return to leadership dwarfs any of the estimated increases in returns to cognitive skills in, for example, Grogger and Eide (1995) or Murnane, Willet and Levy (1995). ${ }^{\square}$ We see this as consistent with Autor, Levy and Murnane's (2001) finding that the spread of computerization has provided low-cost substitutes for certain types of cognitive and manual tasks, while complementing "interactive" tasks. It is also consistent with widely-discussed increases in residual wage inequality and in the relative pay of U.S. executives over this period (e.g. Juhn, Murphy and Pierce 1993; Murphy 1999). Finally, although we find some evidence of intergenerational transfer of leadership skills, we also present evidence suggesting that these skills can be taught. Using school-level leadership opportunities as an instrument for individual leadership substantially increases the estimated returns to leadership.

\footnotetext{
5 Indeed, in a recent review of all the available estimates, Bowles, Gintis and Osborne (2000) argue that no increase in the economic returns to IQ are detectable over the any of the past fourty years.
} 
In the course of our analysis, we conduct several additional exercises to ensure that our measure of leadership is not acting as a proxy for some other physical or psychological characteristic. In two of our data sets we are able to add controls for "beauty" or physical attractiveness; in one we can also control for height. Even though "beauty" affects earnings exactly as expected (Hamermesh and Biddle 1994, 1998; Averett and Korenman 1996), in neither case does accounting for the effects of beauty change the estimated leadership coefficient. Adolescent height does not have a significant effect on adult earnings in our data. We also present instrumental variables evidence that argues against interpreting our estimated leadership effect as a proxy for measurement error in cognitive ability.

Finally, controlling for a very rich set of psychological characteristics available in the Project Talent data (including "vigor", "maturity", "self-confidence", and "tidiness") explains very little of the leadership coefficient. Significantly in our opinion, the largest reduction in the leadership coefficient occurs when we add a control for "sociability" (a self-assessed measure of enjoyment of being around people). We take this as confirmation that our leadership variable is capturing some sort of social skill, or even "emotional intelligence" (Goleman 1997).

Our final piece of evidence that leadership captures some kind of social skill involves occupational outcomes: ceteris paribus, high-school leaders are more likely to be managers as adults. At the same time, however, occupational choices explain very little of high school leaders' earnings advantage. This is because most of the "leadership-wage effect" operates within very narrowly-defined occupational groups. Significantly, the marginal market value of extra leadership skills is considerably greater within managerial occupations than within other occupations. Still, leadership skills are also rewarded within nonmanagerial occupations, suggesting that the leadership-development activities may produce better "followers" or team members as well as better managers.

The research in this paper forms part of a growing literature on the importance of noncognitive skills in wage determination. Much of this literature is reviewed in Bowles, Gintis and 
Osborne (2000); it includes papers examining the effects on adult outcomes of childhood measures of aggression and withdrawal (Osborne 1999); of both child and adult measures of "locus of control" (Goldsmith, Veum and Darity 1997, Osborne 1999, and Coleman and DeLeire 2000); of measures of motivation (Goldsmith, Veum and Darity 2000), and of indicators of behavioral problems during high school (Cawley, Heckman and Vytlacil 2001). The current paper differs from this research in its focus on a skill that firms explicitly say they seek in new hires, and that firms actually pay to foster among their incumbent workers. ${ }^{6}$ Our work also relates to a recent group of papers on the labor market effects of high school athletic participation (Anderson 2000; Barron, Ewing and Waddell (2000); Eide and Ronan 2000; Stevenson 2000.) All of these papers find that participation in high school athletics has small positive effects on adult wages. Our work differs from these papers in its focus on leadership, and in the richer set of measures and additional sensitivity testing that is possible in our three data sets, especially the much larger and more comprehensive Talent data.

\section{Data and Methods}

As noted, we use three data sets. All are surveys of a representative sample of U.S. highschool students, who were re-interviewed at some time between 9 and 13 years after leaving high school. Aside from providing information from three different decades, each of the data sets has some unique advantages that contribute to our understanding of leadership effects. In all three data sets, we restrict our attention to white men.

The earliest of the data sets, the Project Talent study of 1960 High School Students, is also by far the largest. The students in this study were surveyed during high school in 1960, and followed longitudinally for eleven years after high school. During the base year, over 400,000

\footnotetext{
${ }^{6}$ Our research is also related to an older literature, mostly in psychology and education journals, linking participation in high school extracurricular activities with positive educational, behavioral and economic outcomes (Spady 1970; Otto, 1975, 1976; Hanks and Eckland, 1976; Otto and Alwin, 1977; Landers and Landers, 1978; Camp, 1990; Gerber, 1996). Our analysis differs from most of these papers in focusing on three large, nationally-representative data sets, and in the extensive sensitivity testing characteristic of modern labor economic methodology.
} 
students --approximately five percent of all U.S. high school students-- responded to a 400question survey, and were given cognitive and psychological assessments. Because the student testing and survey process lasted two full days, Talent also has a much more complete inventory of personality, behavioral, and ability measures than all the more recent nationally-representative data sources, including the PSID, NLSY, NLS-72, and HS\&B. In this paper we restrict our attention to students who were interviewed as seniors, juniors, or sophomores in 1960, who graduated high school, and were re-interviewed eleven years after finishing high school (in 1971, 1972, or 1973). Aside from its size and focus on multiple years of high school, a key distinctive feature of Talent is the framing of its leadership activity measure: in contrast to NLS72 and HSB (which refer to the senior year only), the Talent survey counts all leadership activity in the past three years. The Talent survey also includes an independent measure of leadership taken from the personality inventory.

The NLS72 followed 1972 high school seniors until 1986. HSB followed 1980 high school sophomores until 1992. In both of these studies, the students were asked about leadership roles and club/sports participation during the senior year of high school only. Other variables are similar to those available in Project Talent. Senior year math scores, parents' education and educational attainment could be coded in exactly comparable ways. ${ }^{\square}$ Unfortunately, the 1992 HSB survey includes only annual, rather than hourly, earnings. It does, however contain a question about physical attractiveness not available in the other surveys, as well as information on participation in three other high school leadership activities that allows us to construct a more continuous measure of leadership.

Two of the three data sets used in our analysis contain plausible measures of leadership in addition to the team and club activity measures. Talent has a self-assessed leadership scale (SILEAD) which was constructed from the respondent's indication that each of the following five statements described himself "extremely well" or "quite well": 
1. I am the leader in my group.

2. I am influential.

3. I have held a lot of elected offices.

4. People naturally follow my lead.

5. I like to make decisions.

These questions were contained in a 150-question Student Activities Inventory designed to assess 13 different personality traits. An individual's score simply sums the number of positive responses. About 38 percent of men in our (weighted) sample agreed with none of the above

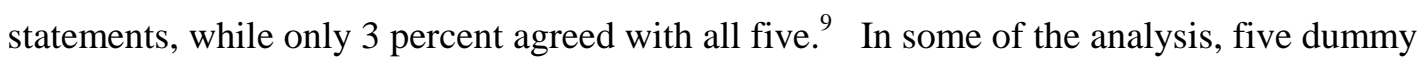
variables distinguish the exact SILEAD score. For other treatments, SILEAD is transformed into a standardized score with mean zero and standard deviation one within each grade cohort.

In HSB, we were able to construct a similar leadership measure by summing the number of distinct types of leadership activities in which an individual had participated during the past year. Two of these are the team captain and club president activities already described. The other three are:

1. Spoke before a group of 50 or more.

3. Headed a group problem-solving session.

3. Chaired a meeting.

Aside from checking the robustness of our results to measurement techniques, these two alternative leadership measures have the advantage of being more continuous than our indicators of club presidency or captainship. This will allow us to explore the functional form of the leadership-earnings relationship in more detail, focusing especially on those individuals with rare and very high endowments of leadership skills.

\footnotetext{
${ }^{7}$ Math scores were made comparable by coding them as percentile scores among white male seniors.

${ }^{8}$ Unfortunately we do not have access to data on the five questions separately, so we are forced to use this "scale" as it was constructed by the original Talent investigators.

${ }^{9}$ This measure is correlated with the leadership activities measure; those who were both captain and president were twice as likely as members of the full sample to agree with four or five of the Silead statements.
} 
Because of the long time interval covered by each of these studies, sample attrition could potentially be a serious problem. The treatment of attrition in the NLS-72 and HSB is already familiar to economists. Weights were constructed by the NCES based on the assumption that non-respondents are similar to the respondents with the same observable characteristics.

The designers of the Project Talent study took a more rigorous and costly approach. In this study, at each resurvey a representative subsample of non-respondents was randomly selected and aggressively pursued. For the white men in this special sample, the researchers achieved a $100 \%$ success rate, making it fully representative of (initial) non-respondents. 10 In our analysis we use weights derived from this aggressively-followed sample to adjust for attrition bias in the larger sample. These weights simply up-weight the responses of this aggressivelyfollowed sample by the inverse of their share of the (initially) non-responding population, to generate means that are representative of the entire 1960 high school population. 1

Descriptive statistics for all three data sets are presented in Table 1. The complete Talent sample includes all 24041 white men who were working at the eleven year interview date, whose measured wages fell between one dollar and fifty dollars per hour, and with non-missing data on math scores and team/club membership/leadership. ${ }^{2}$ Preliminary analysis consistently showed no relationship between verbal scores and later earnings, after controlling for math scores. Rather than lose observations with missing verbal scores, the verbal score was dropped from all further analysis.

Consistent with other evidence on time trends in the supply of college-educated labor (Card and Lemieux 2001), there is actually a slight decline between 1971 and 1991 in the fraction of male high school seniors going on to a college degree. The fraction pursuing some postsecondary education did, however, rise substantially. The fraction of men whose parents had

\footnotetext{
${ }^{10}$ As a last resort, collection agencies were used to locate recalcitrant respondents.

${ }^{11}$ Special sample respondents represent 6.7 percent of individuals in the sample used for analysis, but 44.1 percent of the weighted sample. To avoid artificially inflating the precision of the estimates, Stata's p-weight option was used throughout the paper.
} 
high school and college degrees also rose substantially between 1971 and 1986. The small decline in these percentages between 1986 and 1991 is likely associated with an unusually high number of missing values for parental education in 1986.13

Turning to our leadership measures, fully $78 \%$ of the Talent men reported that, within the past three years, they had participated both on athletic teams and in clubs or other organizations; an additional $18 \%$ participated only in clubs, and another $3 \%$ only on teams. Almost 58\% (.218+.138+.221) had taken some leadership role (either as a team captain or club president) during that three-year window. Because this is such a large group, much of our analysis in what follows focuses on a smaller group of individuals exhibiting more intense leadership activity. In Talent, this is the $22 \%$ of men who reported that they had served both as captain of an athletic team and as president of a club or other organization over this period.

Leadership activities in the NLS72 and HSB samples are described in the last two columns of Table 1. As in Talent, these samples are restricted to those working at the survey date and earning wages that are not in the extreme tails of the distribution. Recall that unlike Talent, these samples consist of high school seniors only (for comparison, summary statistics for only the seniors in Talent are reported in column 2). More importantly, the leadership activity questions refer only to the past year, rather than the past three years. Only 5.8 percent of NLS72 men were both team captains and club presidents in their senior year, and this was true of 11.9 percent of men in HSB. 14

Is leadership just another manifestation of greater "general" intelligence $(g)$ ? While we explore the separate effects of leadership and cognitive skills in considerable detail later in this

\footnotetext{
${ }^{12}$ Despite significant sample attrition, Table 1 shows that our usable Talent sample is more than eight times as large as our NLS72 sample and more than ten times the size of our HSB sample.

${ }^{13}$ To avoid the (likely nonrandom) loss of large numbers of observations due to missing (own and parental) education, we include observations with missing education in our regressions, adding a separate education category for these observations in each case.

${ }^{14}$ Some insights into the sources of this drop can be gleaned from seniors in the National Educational Longitudinal Survey (NELS), who were asked one-year leadership questions three times: 1988, 1990 and 1992 . NELS tabulations suggest that most of the drop can be accounted for by the change to a one-year question, rather than to a decrease in the prevalence of leadership opportunities in high schools over time.
} 
paper, it is instructive at the start to simply look at the joint distribution of these two traits in the population under study. Note first from Table 1 that the mean percentile math score in all of our samples is close to 50, which confirms that our weighting procedure removes any obvious effects of attrition bias. 15 Next, consider that exactly half of the 1960 seniors who had been both captains and presidents in the last three years had math scores above the $50^{\text {th }}$ percentile: in other words, math scores and leadership were essentially orthogonal in 1960. While the association between math scores and leadership seems to have strengthened over time (in the 1972 and 1982 cohorts of seniors, 63 and 66 percent --respectively-- of the "both" group had math scores above the $50^{\text {th }}$ percentile), it seems clear that even in the most recent survey, the correlation between these two skills remains weak.

\section{Results: Leadership and Earnings}

\section{a. Leadership Activities: Captains and Presidents}

Table 2 presents log hourly earnings regression results for the Talent sample, eleven years after leaving high school. Column 1 shows the simple correlations between our high school leadership measures and wages; it shows that, on average, men who were either team captains or club presidents (but not both) between 1958 and 1960 earned 4.7 to 5.4 percent higher wages eleven years after high school graduation. Men who were both captains and presidents earn 7.7 percent more than those who held no leadership position. Column two adds controls for participation in sports or club activities (whether as a leader or not) and for parents' educational attainment. It shows that, while team and club membership are associated with higher earnings, the leadership effect is distinct from these participation effects. Men who were both club presidents and team captains earn over 5 percent more than men who simply participated in both those activities. Similarly, although those with better educated parents tend

\footnotetext{
${ }^{15}$ Percentile math scores were calculated using all base year observations, including those not matched in the followup survey.
} 
to earn more as adults, the leadership effect cannot be accounted for by differences in parental education. ${ }^{16}$ Column three of Table 2 adds controls for cognitive test scores - another variable which is determined before labor market entry. As expected, this variable has a significant effect on wages. However, controlling for cognitive scores has essentially no effect on our "captain and president" coefficient. Indeed, the stability of this coefficient (which for brevity we henceforth call the "leadership wage effect") in the face of controls for cognitive ability confirms the evidence presented in Section 2 that these two skills were essentially uncorrelated in 1960.

Because educational attainment beyond high school is properly seen as endogenous in the current context, it is not clear that we should control for it as regressor. However, to understand the extent to which the market returns to high school leadership are driven by differences in educational choices between individuals with different levels of leadership skills, column 4 adds controls for the respondent's further education. This reduces the "captain and president" coefficient by about 20 percent (from .053 to .042) suggesting that less than one quarter of the leadership effect works "through" further education decisions. ${ }^{1}$ This suggests that our leadership coefficient is capturing something other than college scholarship opportunities, or personal characteristics such as "persistence" or good study habits associated with continuing on in school.

Columns 5-8 estimate models identical to columns1-4 but with the addition of fixed effects for each of the 1005 high schools in our Talent data. Effectively, these regressions compare respondents only with others who attended the same high school, as a way of controlling for omitted family background, school, peer and neighborhood quality effects, as well

\footnotetext{
${ }^{16}$ The results are robust to including controls for student-reported family income. This variable was dropped from the analysis because it was missing for about one-third of the sample, and to maintain comparability across data sets. Within this smaller sample, using the specification of Table 2, Column 7, but including controls for the log of family income and an indicator of father's employment in a professional, managerial or technical occupation has very little effect on the estimates: there is only a tiny drop in leadership coefficients (less than one-third of the standard error for all 3 leadership categories).

${ }^{17}$ However, it is worth noting that the high school leaders do have greater educational persistence at every level of attainment. Compared to other high school graduates, those who were both captains and presidents are $18 \%$ more likely to have completed at least some college, $24 \%$ more likely to have completed a college degree, and $38 \%$ more likely to have completed a graduate degree, despite having virtually identical cognitive test scores.
} 
as any other factor associated with the high school attended. The most surprising thing about these regressions is how similar each one is to the corresponding regression without fixed effects: the leadership effect never differs by more than four tenths of a percentage point. We take this as strong evidence that our leadership variables are not acting as proxies for unmeasured aspects of the student population that vary systematically across schools.

Table 3 presents earnings regressions from the NLS72 and HSB data, constructed to be as similar as possible to the Talent regressions. In all cases we present only those specifications that include a full set of high school fixed effects. $\frac{8}{}$ As noted, unlike Project Talent, in each of these newer data sets we can only look at a single cohort of individuals (persons interviewed as seniors in 1972 and 1982 respectively). Also, in one of the two data sets (HSB) we do not have access to a true hourly wage measure; instead we only know total annual earnings. To address these potential noncomparabilities, columns 1-4 of Table 3 present (log) annual earnings regressions for seniors only in Project Talent. These are very similar to those for the full Talent sample in Table 2; thus we can be quite confident that any differences in the results between our three data sets are not driven by differences in the high school interview year, nor by the use of hourly rather than annual earnings as the dependent variable. This should not be surprising since, in all years, the overwhelming majority of young adult white men work full time and full year.

Turning to the NLS72 and HSB results in columns 5-12 of Table 3, it is clear that (a) returns to math scores remained remarkably similar over this time period, while (b) the estimated returns to leadership skill appear to have risen dramatically. Compared to the 1960 cohort, leadership coefficients are more than twice as large for the 1972 cohort and more than four times as large for the 1980 cohort. ${ }^{1.9}$ Having ruled out the difference in annual versus hourly earnings

\footnotetext{
${ }^{18}$ In the NLS72, with its high school-to-person ratio, note that the full set of school dummies results in a particularly low adjusted R-squared. The coefficients of interest however are very similar to the specification without school effects.

${ }^{19}$ Wage effects of simple participation in sports or clubs seem however to have declined between 1982 and 1992. Recall however that the coefficient for "both" measures earnings relative to nonparticipants, a comparison which is
} 
and the choice of the senior year versus other years of high school as an explanation of this, and recalling that the variable definitions, sample restrictions, and regression specification are in other ways identical across the three waves of data, we can think of only two remaining sources of noncomparability between these regressions. One relates to differences in the number of years after high school graduation when earnings are measured: eleven, fourteen, and nine in Talent, NLS72 and HSB respectively. While evidence that the leadership wage effect increases with experience (see Section 4 below) might explain a portion of the difference between the Talent and NLS72 results, it cannot explain the increase between 1986 and 1991, or between 1971 and 1991, both of which occurred in the face of declining labor market experience in the sample.

A second possible concern is the difference in three-year versus one-year windows for measuring leadership in the Talent versus the other two data sets. Could the smaller estimated returns to leadership in the Talent data set occur only because the larger group of individuals identified by its three-year leadership activity question contains a higher fraction of individuals who are not "true" leaders - persons who, perhaps accidentally, were assigned a captainship or club presidency for a very short time during this long interval? We address the issue of observation windows and misclassification in Appendix 1, and show that it is extremely unlikely that the difference in observation windows alone can account for the difference between our 1971 and later leadership coefficients. In brief, the reasoning is as follows. Suppose for simplicity that in each year of high school a fixed number of persons without leadership skill are assigned to leadership positions and (because those positions are then occupied) the same number of "true leaders" do not occupy leadership positions. Then clearly our coefficients on occupying a leadership position understate the "true" wage effect of having leadership skill. It is not, however, clear, that this attenuation bias is greater using a three-year or a one-year measure of leadership activities. Certainly, as argued above, a three-year measure such as Talent's

unaffected by changes in the "participation" coefficients. Note also that the coefficients on having served only as captain or president are closer to the coefficients on doing both in the two later cohorts. This is to be expected with the 
(whether one ever occupied a leadership position in three years) gives nonleaders more chances to be misassigned into leadership roles, but it also raises the certainty that those who never occupied a leadership role are not true leaders. and show that the relative attenuation bias of a three-versus a one-year measure has a inverted Ushaped relation to the amount of measurement error. Using the maximum possible amount of relative bias, a simple calculation then shows that no amount of measurement error can account for the difference in coefficients we observe between Talent and the other two data sets.

A final piece of evidence that the true wage returns to leadership skill have increased is provided in the following subsection, where we use an alternative measure of leadership skill that allows us to isolate a group of the same relative size ---the top three percent of the leadership skill distribution-- in 1971 and 1992. As suggested by the preceding analysis, we find that the top three percent had a much larger advantage over workers in their cohort in 1992 than in 1971.

In sum, this section suggests that, in contrast to the relative stability in the returns to cognitive skills over this period, there was a large increase in the wage returns to leadership skills between 1971 and 1992 in the U.S. economy. This trend coincides with a dramatic decrease in the price of computing power, and with a change in work organization away from Taylorist management towards increased employee involvement and teamwork (Lindbeck and Snower 2000). It is certainly tempting to speculate that these changes have contributed to an increase in the demand for social, rather than strictly cognitive, skills.

\section{b. Other Measures of Leadership}

\footnotetext{
one year leadership activities questions because many of those who filled one role their senior year are likely to have filled the other role in a previous year.

${ }^{20}$ Note therefore that the process of restricting the number of measured leaders by moving to a one-year observation period is fundamentally different from focussing on a subgroup with more intense leadership activity during a given observation period (as we do when we restrict attention to those who are both leaders and captains, or focus on higher levels of self-assessed leadership). The latter should always increase the estimated leadership wage coefficient, as it does in all of our estimates.

${ }^{21}$ Another possible explanation is supply- rather than demand-based. As Christopher Jencks has suggested to us, perhaps the decline in civic engagement documented by authors like Putnam (2000) has reduced the effective supply of leadership skills at the same time that the demand has risen.
} 
Table 4 reports similar regression results to those in Tables 2 and 3, but using the alternative measures of leadership described earlier in Project Talent and HSB. Because both of these measures take six ordered values, they can give us a better idea of the functional form of the leadership-wage relationship, especially in the upper tail of the leadership distribution.

Recalling that about 20 percent of the Talent sample were both a team captain and a club president in the three years preceding their high school interview, the Talent results in the first four columns of Table 4 are broadly consistent with those in Table 2: Looking at the most highly-parameterized specification in column 4 , those in the $80^{\text {th }}$ to $90^{\text {th }}$ percentiles of selfassessed leadership ability $($ SILEAD $=3$ ) enjoyed a 5.3 percent wage advantage 11 years after high school over those in the bottom 38 percent. (Recall that, using the leadership activity measures, the top 20 percent enjoyed a 3.8 percent advantage over the bottom 58 percent.) The main new information provided by Table 4 concerns those individuals with very rare, and very high levels of (self-assessed) leadership ability: these persons enjoy much larger earnings advantages 11 years later than those with only moderate self-assessed leadership skills. For example, the top three percent enjoy a wage advantage of just under 16 percent, which is higher than the effect of completing a bachelor's degree in this data. 2

Results for our HSB leadership measure based on a count of five different types of high school leadership activities (including captainship and presidency) are shown in columns 5-8 of Table 4, and are very similar in pattern. The main difference is an even higher wage premium, of over 28 percent, earned by the top 3 percent of high-school leaders. This evidence, based on a

\footnotetext{
22 Because all respondents in each of these data sets attended high school at the same time and were re-interviewed at the same time, our education coefficients need to be interpreted with care: persons with a college degree have, on average, four years less work experience than those with only high school. This collinearity between education and experience explains why we do not include an experience indicator in our earnings regression, and explains the relatively low returns to education we estimate. Of course this does not affect the quality or interpretation of our leadership coefficients because the one variable (education) suffices to hold both education and experience constant.
} 
fraction of the high-school population of the same size in both 1971 and 1992, reinforces our conclusion that the economic returns to leadership skills increased between these two years.

The relationship between leadership skill and the natural logarithm of wages implied by the Table 4 coefficients is presented graphically in Figures 1 and 2. Clearly, both relationships are convex in logs, and are therefore highly convex in levels, as suggested by models of managerial task assignment and reward such as Rosen's (1982). This increases our confidence that our measures are capturing the kind of skill that such models have in mind.

\section{The Structure of the Leadership Effect}

Section 3 has, we believe, convincingly demonstrated that men who occupied leadership positions in high school, or who perceived themselves to be leaders while in high school, earn more as adults, even when traditional measures of human capital and cognitive skill are held constant. But is this necessarily because they possess a particular skill in dealing with groups of people? In the current section, we argue that additional clues to the true source of the leadershipwage effect can be obtained by asking whether this effect differs substantially in size and significance across population subgroups. For example, if the leadership-wage effect is confined to those men who went on to college, it might be simply that high-school leadership activities provide access to higher-quality colleges, both by impressing admissions committees and via the financial support of scholarships, athletic and otherwise. If the leadership-wage effect is confined to those with high mathematics test scores, leadership skill might be more accurately viewed as similar to calculus: a skill which any "high-g" person could acquire if he or she chose to, but one

\footnotetext{
${ }^{23}$ Given the relatively small size of the HSB data set and the small fraction of men (3\%) in this top leadership category, we were concerned that this very high estimated coefficient of .288 could just be a statistical fluke. While the effects of any pure statistical noise should be reflected in our standard errors, to increase our confidence in these estimates we used the fact that HSB respondents are interviewed about their earnings annually, rather than just once. When we replaced our one-year measure of earnings by an average over the last two years in which the HSB sample was observed, the estimated coefficients on the five leadership categories in column 8 of Table 4 changed to .406(.116), .153(.055), .156(.054), .154(.049) and .032(.038) respectively. Thus a better measure of permanent income yields an even higher earnings advantage of the top 3 percent of leadership skills of over $40 \log$ points. We conclude that the high leadership coefficient in 1992, and the increase in returns to leadership skill between 1971 and 1992 is not a statistical "fluke".
} 
which is impossible or very difficult for low- $g$ persons to acquire. If so, one might question whether it was really distinct from " $g$ ". Although --for reasons already discussed-- the Talent data has the smallest estimated leadership coefficients of the three data sets available to us, we conduct all our analysis of these interaction effects using the Talent data because of its much larger sample size.

Leadership-wage coefficents within math test score groups, within own-education groups, and within parental-education groups from the Talent data are reported in Table 5. Separate regressions, identical to those in column 8 of Table 2 except for the interactions, were run to estimate each of these sets of interactions. Leadership wage effects, for both types of leadership measures used in this paper, are essentially identical for persons above and below the median math score. In our opinion this strengthens the case that leadership ability is something quite distinct from general intelligence, " $g$ ". With the exception of the "captain only" coefficient, the same is true for the respondent's own education: leadership wage effects are the same for persons who completed a bachelor's degree as for those who did not. Somewhat surprisingly, being a team captain (but not a club president) during high school has a significant effect only on the wages of individuals who did not go on to finish college. Perhaps, as suggested by assignment models such as Roy's (1951) in which persons specialize in the use of their "best" skill only, the social skills of team captains are particularly valuable (on the margin) to persons with lower levels of other kinds of human capital.

Finally, the evidence regarding parents' education is more mixed, perhaps because the sample is now divided more finely into three education groups: leadership activities seem to have a bigger wage effect among students with highly-educated parents, while self-assessed leadership matters more among students whose parents did not complete high school. In sum, none of our evidence indicates that the leadership-wage effect is confined to one readilyidentifiable population subgroup. Instead it is broadly detectable across groups with different 
math test scores, own education, and family background. ${ }^{24}$ This increases our confidence that leadership really is a distinct skill, rather than a byproduct of some other skill or characteristic.

A final kind of interaction effect is explored in Table 6: interactions with labor market experience. Unlike the other data sets used here, the HSB data have the advantage of providing retrospective annual earnings snapshots of individuals in each of several consecutive years, allowing us to estimate an experience effect that is distinct from an education effect, and to ask whether the leadership effect interacts with experience. For this analysis, we focus on a sample of individuals who reported positive earnings in every year from the sixth through the ninth year after high school. 5 To insure that most had completed their formal education by the sixth year after high school, we dropped all individuals who reported having a graduate degree ten years after high school.

Table 6 clearly shows that the effects of high school leadership on earnings increase substantially between the sixth and ninth year after high school. ${ }^{66}$ For example the earnings advantage of persons who were both leaders and captains in high school increases monotonically, from 5.2 percent in 1988 to 13.4 percent in 1991, becoming statistically significant at conventional levels in 1990. Such an increase could be caused by at least two possible processes. One of these is a "general learning" effect of the sort modelled by Farber and Gibbons (1996), where leadership takes the place of the AFQT in their analysis. Farber and Gibbons argued that cognitive ability, as measured by AFQT, is not directly observed by employers, but that the market learns this and it becomes reflected in wages as a worker gains

\footnotetext{
${ }^{24}$ We conducted a similar exercise to those in Table 5 using family income (during high school) as our measure of family background (recall this information was available only for a considerably smaller sample, and may be subject to more measurement error than parents' education. Self-assessed leadership had a strong and significant wage effect among low, medium and high family income groups. The pattern for the three leadership activity measures ("captain", "leader" and "both") was more complex, but looking across all the measures, positive leadership effects were seen at both ends of the income distribution.

${ }^{25}$ Those with very high or very low earnings in any year were dropped, with the earnings thresholds the inflationadjusted equivalents of those used in the preceding tables.

${ }^{26}$ While the "captain only" coefficient is an exception to this trend, this appears to be related to differences in educational attainment. Within the college educated group, the captain-only coefficient grew from .04 (.06) in 1988 to .22 (.06) in 1991. This is comparable to growth of the "both" coefficient within the college-educated group:.05 (.07) in
} 
labor market experience. It seems plausible that a similar process could apply to leadership skills. A second interpretation of this result is a genuine productive complementarity between leadership and experience: It also seems plausible that one needs to develop some substantive expertise in a given kind of work before one can profitably apply one's leadership skills in it.

Given the steady growth in the returns to leadership between ages 24 and 27, and given their appreciable size in the ninth year after high school, one can only speculate about the size of leadership wage effects for workers later in life, when workers have had more time to rise through promotion ladders and to actually assume higher-ranked leadership positions. One suspects that the effects may be large enough to help us understand employers' current high level of expressed interest in this trait.

\section{Alternative Explanations for the Leadership Effect}

In this section we consider three alternative explanations of the leadership-wage effect that are not consistent with our argument that high school leadership activities measure a type of social skill. While some of these alternative processes do turn out to have important effects on adult wages, we show that they cannot account for the robust and increasingly-important leadership-wage effect observed in the analysis so far.

a. Is it just measurement error in " $g$ "?

One alternative explanation of the leadership-wage effects documented in Tables 2 through 6 is that our math test is a noisy measure of some underlying level of cognitive ability, and that leadership acts as a proxy for this unmeasured, permanent component of " $g$ ". Intuitively, suppose that students with high "true" levels of $g$ are more likely to assume leadership roles in high school, but that leadership roles have no causal effect on earnings (nor

1988 to .30 (.05) in 1991, and to the growth of the the "president only" coefficient among this group as well: -.06 (.06) in 1988 to $.17(.05)$ in 1991. 
are they indicative of any skill other than $g$ that the student might possess). Then, if a math test administered in any given year measures "true" $g$ with error, leadership ability will still appear to have an independent effect on wages. In essence, the leadership variable will capture those "smart" people who just had a (random) bad day when the test was administered. 27

If we had access to data containing multiple measures of $g$ for the same person, we could test the above measurement error hypothesis using instrumental variables. Fortunately, students in the HSB data were given similar math tests in both the $10^{\text {th }}$ and $12^{\text {th }}$ grades. Assuming independence of measurement error across tests, we can therefore correct for measurement error in math scores by using the $10^{\text {th }}$ grade score as an instrument for the $12^{\text {th }}$ grade score. When we do this, as expected the measured return to math scores in column 12 of Table 3 increases - in fact it more than doubles. More importantly, however, the returns to being a president only, captain only, or "both" are essentially unchanged. We conclude that measurement error in the cognitive skills measured by math scores does not explain our estimated wage effects of leadership skills, including the very high leadership effect we find in the most recent year of our data, 1992.

\section{b. Is it Beauty? Or Height?}

Another alternative explanation of our result is that the leadership variable is acting as a proxy for a very different unobserved determinant of earnings: "beauty" or physical attractiveness (Hamermesh and Biddle 1994; Averett and Korenman 1996; Biddle and Hamermesh,1998). It is therefore still possible that teams and clubs select physically attractive persons into "leadership" roles, and that the labor market's propensity to reward beauty, not the managerial or other social skills these people possess, explains our results. Relatedly, personnel

\footnotetext{
${ }^{27}$ Note that this argument implies that leadership and math scores should be positively correlated in the sample as a whole. As noted earlier, this is actually not the case for the leadership ability measure in Talent, but $i s$ true for other definitions of leadership and in our other data sets. Since we are particularly concerned with the accuracy of the high estimated leadership effect in HSB (where, incidentally, leadership and math scores are most highly correlated), it is
} 
psychologists have presented evidence that, ceteris paribus, tall people are more likely to win promotions into managerial positions and to receive favorable job evaluations (see for example Melamed and Bozionelos 1992). Thus it is also possible that tall people are disproportionately selected into leadership roles in both high school and the world of work, and that their stature alone explains their higher wages.

While we do not have as detailed measures of "beauty" as the two Biddle/Hamermesh papers had, we can still test the beauty hypothesis in two of our three data sets. HSB contains a measure of self-assessed beauty in the question "Others think I'm unattractive". Talent contains the height and weight information which (a) allow us to assess the "height" hypothesis, and (b) allow us to compute each respondent's body mass index (BMI): the "beauty" indicator used by Averett and Korenman. While neither of our beauty measures will allow us to identify individuals who are exceptionally attractive, Hamermesh and Biddle (1994) find that the most important effects of beauty on earnings occur at the lower, not the upper tail of the beauty distribution, effects which should be well captured by our measures here.

Part (a) of Table 7 reports the HSB beauty and leadership coefficients from identical regressions to those in columns 9-12 of Table 3, with beauty coefficients added. In HSB, the beauty variable is clearly capturing something that affects earnings as expected, with individuals who report that others think they are unattractive earning 14 percent less. Interestingly, however, this coefficient halves in size and becomes insignificant when high school fixed effects are added to the regression. More importantly, the estimated leadership effect in column 6 of Table 7(a), at .227 , is almost identical to that without beauty controls, .244, in Table 3, column 12 .

Adding BMI and height to the Talent regressions has similar effects, shown in parts b and c of Table 7 for the "activity based" and self-assessed measures of leadership respectively. In these regressions, note first that BMI does affect earnings as one might expect: those who are

particularly fortunate that HSB is the one data set where we have access to multiple math tests for the same person, which we use to assess the role of measurement error below. 
substantially overweight in high school face significant earnings penalties as adults (again, the difference in timing avoids endogeneity issues: in this case the possibility that poor labor market outcomes might cause extreme weight gain). Persons who are underweight also earn less later but the coefficient is insignificant in most specifications. Although there is some indication that short people earn less than others, the height coefficients are generally insignificant as well. Most importantly, adding controls for both BMI and height has essentially no effect on either the activity-based or self-assessed leadership coefficients.

While our measures of beauty are not as detailed as we would like, the above results make it quite unlikely that the leadership effects identified in this paper can be explained by pure beauty effects. For one thing, a "pure" beauty explanation would require that athletic teams choose their captains purely on the basis of physical attractiveness, rather than their athletic ability or their social skills with their teammates. Further, the concentration of our estimated leadership effect near the top of the distribution of leadership skills also argues against a "beauty" interpretation, given Hamermesh and Biddle's results. Clearly, our results are more consistent with a Rosen (1982)- type model in which persons with high leadership ability are matched with jobs where leadership skill has a greater marginal effect on productivity, generating especially large wage differentials at the top of the leadership distribution.

\section{c. Is it some other psychological characteristic?}

When economists discuss the residual in earnings regressions, a long list of psychological traits, such as "drive", "energy", "work ethic", "persistence", and "motivation" are usually mentioned in addition to factors like IQ. Most data sets, of course, do not allow the effects of these traits on earnings to be distinguished. In the Talent data, however, we have a unique opportunity to ask whether our leadership coefficients are acting as proxies for such other (presumably productive) psychological characteristics, or whether they are more specifically associated with a skill in motivating and co-ordinating groups of people as we have been arguing 
here.

To distinguish the leadership effect from other personality characteristics that might affect earnings, Table 8 examines returns to other self-assessed psychological characteristics measured in the Talent data. Each of these measures is constructed in a manner similar to the SILEAD measure of leadership, from different questions within the same 150-item instrument. The measures include "sociability" (based on 12 questions such as "I'd rather be with a group of friends than at home by myself" and "I enjoy getting to know people"), "tidiness" (11 questions such as "'I am never sloppy in my personal appearance" and "Before I start a task, I spend some time getting it organized"), "vigor" (7 questions such as "I can work or play outdoors for hours without getting tired" and "I am full of pep and energy"), self-confidence (12 questions such as "People seem to think I usually do a good job on whatever I'm doing" and "I'd enjoy speaking to a club group on a subject that I know well"), mature personality (24 questions such as "I do my job, even when I don't like it," "I can turn out a lot more work than average," "I do things the best I know how, even if no one checks up on me," "I think that if something is worth starting, it's worth finishing," "I am dependable," "People consider me persistent," "I am conscientious" and "I am reliable"). For easy comparison, all of these measures are standardized to have mean zero and standard deviation 1 within each grade cohort.

The first six columns of Table 8 describe regressions in which these additional psychological measures are added to our Talent leadership regressions one at a time. The upper portion of the table adds the additional psychological measures to the wage regressions that used the self-assessed leadership measure (SILEAD); the lower portion does the same for the wage regressions which use our activity-based measures of leadership. In the lower portion of the table we report only the leadership coefficients; the coefficients on the other psychological measures are very similar to those in the top half of the table.

Looking at the effects of these newly-introduced psychological measures in the top half of the table, it is clear that (when added on its own) each one of them has a statistically 
significant, positive effect on $\log$ wages, with coefficients ranging from .012 (.004) to .027

(.004). Importantly, however, none of these psychological traits on its own, nor all of them combined, reduces the estimated leadership effect to insignificance: controlling for all five measures, the leadership coefficient remains strongly statistically significant at $.024(.005)$. Of these additional personality measures, the sociability index stands out, causing the largest reduction in the SILEAD coefficient, from .037 (.004) to $.027(.005)$. The last three rows of Table 8 show that similar results obtain when the behavioral measure of leadership is used. We conclude that leadership is not simply capturing any of these other, potentially productive psychological traits. If anything, we take the largest attenuation of our results when "sociability" is controlled for as further confirmation that our leadership variable is capturing some sort of social skill, or even "emotional intelligence" (Goleman 1997).

\section{Leadership Skills and Adult Occupations}

If our measures of leadership are truly picking up a skill that is useful in motivating groups of people, we should expect to find that (as Rosen's 1982 model suggests) persons with these skills will be assigned to occupations -such as managerial ones—where these skills are most useful. To address this question, Table 9 shows the relationships between our leadership measures and entry into managerial occupations. ${ }^{8}$ Table 9 shows that men who acted in any leadership capacity in high school (captain, president or both) are 3.5 percentage points more likely to occupy a managerial job 11 years later, compared to men who attended the same high school with the same math scores, parental education, and own education. There is apparently no

\footnotetext{
28 "Managerial" occupations include the following categories of occupation, selected from 58 pages of identified jobs: Business management, administration or supervision (e.g. foreman, sales manager, office manager, executive, bank president, engineering manager, data processing manager/supervisor, production manager, personnel administrator), public administration (e.g. government administrator, hospital administrator, school principal, college dean, park administrator, youth director or leader), artistic director (e.g. musical conductor, theatrical director or producer), and military officer. In our sample, $15.7 \%$ were employed in one of these "managerial" occupations, $87 \%$ of those $(13.6 \%$ of the sample) in the business management, administration or supervision category. A detailed list of managerial occupations is available on request from the authors.
} 
additional effect from more "intense" high school leadership activity. Mirroring this result, having a self-assessed leadership score above the $65^{\text {th }}$ to $80^{\text {th }}$ percentile also raises the probability of occupying a managerial job, but no additional effects are found at higher percentiles of the leadership skill distribution.

Table 10 presents the results of wage regressions that control for selection into a managerial occupation. These results shed some important light on the relatively weak effect of "intense" high-school leadership on selection into managerial occupations noted above, by showing that most of the effect of leadership on earnings is primarily through channels other than selection into a managerial job. In fact, most of the return to very high levels of leadership skill takes the form of higher wages within managerial occupations. To see this, note first (comparing columns 1 and 2) that adding fixed effects for very detailed (a total of 694) occupational categories has only a very small effect on our estimated leadership wage effects. ${ }^{29}$ For example, when subsequent educational attainment is not held constant (columns 1 and 2), the wage return to being both a captain and a president falls by about thirteen percent (from 5.5\% to $4.8 \%$ ) when occupation controls are introduced. When educational attainment is held constant (columns 4 and 5), adding occupation controls does not change the estimated return to leadership activity at all. Next, comparing columns 2 and 3, or 5 and 6, note that leadership skills are rewarded both in those occupations we classified in Table 9 as managerial, and in other occupations, but that the marginal rewards are greater in managerial occupations. In all cases, the return to leadership in nonmanagerial occupations is only slightly smaller than in Table 2 (which estimates a population-weighted average effect). For example, looking within nonmanagerial occupations in column 6, the "both" group earns 4.2 percent more than other men. Within managerial occupations, however, this rises to $(4.2+2.7=) 6.9$ percent. A more dramatic (and statistically significant) difference is evident for team captains. Finally, a one-standard deviation increase in 
self-assessed leadership raises wages by 2.1 percent in nonmanagerial occupations, but by $(2.1+$ $3.8=) 5.9$ percent in managerial occupations, a highly significant difference. .0

Taken together, two of the results which emerge very clearly from Tables 9 and 10 --the greater likelihood that high-school leaders occupy a managerial position as adults, and the greater economic return to leadership skills within managerial versus other occupations—strike us as strong evidence that our measure of leadership skill in this paper captures a social skill that is useful in managing or motivating groups of people. At the same time, we are intrigued by two other results of this section: (a) the fact that most of the wage effects of leadership skill operate within, not between, very detailed occupational groups, and (b) even among men who do not occupy management positions as adults, those who engaged in leaderhip activities during high school earn higher wages. The latter observation suggests that, if leadership skills could be taught, these efforts would not necessarily be wasted on those individuals who do not turn out to be managers-leadership skills might make one a more effective "follower", or work group member, as well as a better manager. Of course this begs the question of whether leadership skills can be acquired, which is the question we address next.

\section{Can Leadership Skills be Taught?}

Consider for a moment two very different models of leadership. In one extreme model, leadership skill is purely innate, or determined before entry into high school. The measures of leadership activity during high school used in our empirical analysis above merely provide observable indicators of the presence of this skill in an individual. According to a second view,

\footnotetext{
${ }^{29}$ To be able to introduce this battery of occupation dummies, we replaced the school fixed effects in column 8 of Table 2 by a continuous variable equal to the log of mean wages in the respondent's state. Comparing the Table 2 results with column 1 of Table 10, it is clear that this has almost no effect on the results.

${ }^{30}$ The high return to leadership within managerial occupations can be further illustrated by a wage regression identical to column (6) of Table 10, but restricted to persons in managerial occupations, that breaks down our continuous selfassessed leadership measure (SILEAD) into a series of dummy variables. Coefficients (standard errors) for SILEAD levels of one through five are, respectively, .057 (.027), .104 (.034), .130 (.032), .208 (.047), and .230 (.049). Although the specifications are not directly comparable, it is still noteworthy that each of these coefficients exceeds its counterpart in column 4 of Table 4.
} 
leadership skills are acquired, at least in part by spending time occupying a leadership position during high school. Schools can produce a larger number of persons with this ability by providing more leadership opportunities (e.g. more clubs and teams, creation of positions such as class presidents, rotation of leadership positions). Even though these two views can have quite different implications for education policy, nothing in our analysis so far allows us to distinguish between them.

In this section we provide two kinds of evidence that may help to distinguish between "innate" (or at least acquired before high school) and "acquired" notions of leadership skill. The first simply asks whether students who take leadership roles in high school tend to have fathers who were leaders (either supervising more than 50 people at work, or having served as a military officer). If so, at least some component of leadership skill would appear to be determined (either genetically or via socialization) before an individual enters high school. When we ran linear probability models for whether an individual was a team captain or club president on the father's leadership variables and a variety of individual and family background indicators (including math scores), we found strong effects. 1 The coefficient on having a father who supervised at least 50 people was .05 with standard error .01 . The coefficient on having a father who had served as a military officer was .04 with standard error .01. This suggests that at least some leadership ability is determined before entry into high school.

The second exercise in this section uses an instrumental variables (IV) approach to isolate the variation in individual leadership that is attributable only to differences in the number of leadership opportunities offered at one's high school. If a higher number of leadership positions in a young man's high school increases his participation in these positions, and thereby raises his adult earnings, this points towards a dimension of leadership skill that is learned after the age of 13. On the other hand, if leadership skills were purely inherited, confining our

\footnotetext{
${ }^{31}$ Other controls included parent education, log of family income, math scores, height, bmi, grade in 1960 and school fixed effects. Those whose fathers were leaders also had significantly higher SILEAD scores.
} 
attention to the variation in individuals' high school leadership activity that is explained only by variation in the number of leadership opportunities in their school should eliminate the positive earnings coefficients found so far in this paper.

IV estimates of leadership-wage effects are presented in Table 11. Table 11 focuses only on leadership activities (not self-assessed leadership) since our question here concerns the possible productive value of occupying those positions, and only on the Talent data set because only there do we have enough observations to permit the use of school-level instruments. Also, to allow us to focus on a single endogenous leadership variable, the Table 11 wage regressions distinguish only between men who were both captain and president in high school and all others. Finally, note that Table 11 presents two kinds of IV estimates. The more traditional (and more widely-used) of these are shown in columns 2, 5 and 8 (columns 1, 4 and 7 provide identicallyspecified OLS results for comparison). This approach estimates a first-stage linear probability model for occupying a high-school leadership position, then uses predicted values from this model as a regressor in the wage equation. The one variable that is included in the linear probability model but not in the wage equation is the schoolwide mean probability that an individual is both a captain and a president. The second approach is full-information maximum likelihood (ML). Here we assume that occupying a leadership position is determined by a probit process with disturbance $\mu_{i}$, and wages by a linear regression model with disturbance $\varepsilon_{i}$. The likelihood of the entire sample when $\mu_{i}$ and $\varepsilon_{i}$ follow a bivariate normal distribution with correlation coefficient $\rho$ is derived in Appendix 2. We estimate this entire system, including $\rho$, using the same exclusion restrictions as in the "traditional" IV case; the results are shown in columns 3, 6 and 9. The advantages of our ML approach are greater efficiency, plus a (probit) functional form that cannot generate negative probabilities of occupying a leadership position in the "first stage" regression. 
Turning to the results, column 1 shows OLS coefficients for a model with the same covariates as column 1 of Table 10. Columns 2 and 3 show IV and ML estimates of the same model respectively. Importantly, rather than declining, the IV and ML estimates of the leadership-wage effect are substantially greater than the OLS estimates, implying a statistically significant 14 to 18 percent wage effect of participating in high-school leadership activities. Some insight into why the estimated effect is larger under IV and ML comes from the significantly negative estimate of $\rho$ in the ML model: according to this model, the unobserved components of individual leadership propensity and wages are negatively correlated, generating a downward bias in the OLS leadership-wage coefficient. Taken together, the results in columns 1-3 constitute evidence against a pure "inherited ability" model, suggesting that high schools can teach leadership skills by providing more clubs and teams, or by rotating leadership positions in those activities.

One might, of course, object that the above test is biased in favor of the "acquired ability" hypothesis because of other high school characteristics that are omitted from our regression. It might be the case, for example, that high schools which provide more leadership opportunities tend to be better endowed in other ways as well, in which case the benefits we are attributing to additional leadership opportunities may actually be the result of the overall educational environment of the school. Also, we have already shown that a component of leadership is "inherited", and it might be the case that high schools offer more leadership opportunities when the incoming student population has a leadership family background. ${ }^{2}$ To address these concerns, columns 4 through 6 of Table 11 include controls for the educational quality of the school (schoolwide average math scores, and schoolwide average gains in math

\footnotetext{
${ }^{32}$ In other words, a plausible objection to our story would run as follows: Parents who are leaders lobby for more leadership opportunities in their childrens' schools. If leadership skills are passed on within families, this can generate a spurious correlation between leadership opportunities at a school and the adult wages of children who attend that school. But there are at least two things wrong with this story. First, for our estimated leadership-wage effect to be explained only by this process, parents would need to behave in an inconsistent manner: they would need to lobby schools for additional leadership opportunities that are totally ineffective. Second, and more importantly, there is in
} 
scores between the $10^{\text {th }}$ and $12^{\text {th }}$ grades), and columns 7 through 9 include further controls for the family background of the student body (the proportion of students in the school with high or low family income, and each student's father's occupation and father's leadership roles). ${ }^{63}$ Recall also that other controls included in all the wage equations include the individual's own math score, his parents' education, the log of the average wage level of sampled students who attended high school in the same state, and the (urban or rural) location of the high school.

In view of the the comprehensive nature of our school quality controls, the results of adding them to the regressions of Table 11 are surprising: there is essentially no change in either the OLS, the IV, or the ML coefficients even though we are now estimating the effect of increasing leadership opportunities in a school holding fixed its overall math scores, its success record in raising math scores, and the fraction of parents in the school who occupy leadership roles in their jobs. We conclude that it is very unlikely that the estimated return to leadership works purely through selection of "natural" or "born" leaders into high school leadership positions which provide no intrinsic learning benefit of their own.

\section{Discussion}

This paper has taken a small peek into the "black box" that labor economists call "unobserved ability". It has taken its inspiration from a quality employers repeatedly list among their most highly-valued attributes when hiring workers, yet which has been largely ignored by economists to date. It has shown, we believe quite conclusively, that indicators of leadership skill taken before labor market entry have robust effects on adult wages. These effects are both economically and statistically significant. They persist in the presence of controls for cognitive skills, parental background, school fixed effects, and educational attainment after high school.

fact no correlation in our data between a father's propensity to occupy a leadership position and the number of leadership opportunities in his son's school.

${ }^{33}$ Dummy variables indicate father's occupation (professional, managerial, technical or not) interacted with workplace supervisory role (supervises 50 or more, fewer than 50 , or no supervisory responsibility). An additional dummy variable indicates whether the father ever served as a military officer. 
Our results suggest (a) that what psychologists call "intelligence" and what labor economists call "ability" has more than one dimension; (b) that the "softer" kinds of skills such as leadership can -like other kinds of human capital-- be acquired in schools; and (c) that the economic returns to these "softer" skills have increased dramatically over the past two decades. Our results also suggest that -despite the lack of economic evidence on this issue to date-- the intensive efforts of many parents and schools to involve children in leadership-development activities during the past few decades have not been misguided. As a consequence, it seems likely that further investigation into "nontraditional" dimensions of skill will improve our understanding of earnings determination and make it more relevant to the widely-expressed needs of employers and educators today. 


\section{Appendix 1: The Effect of One-Year versus Three-Year Observation Windows in the Presence of Misclassification Error}

Let the fraction of "true" leaders (those who possess a leadership skill that will be rewarded in the labor market) in a high school be $p$. Suppose that our only observable indicator of whether an individual possesses this skill is whether he occupies a leadership position in a given year, and that there is a fixed number of leadership positions in the school, equal to $p$ as well. Let $r$ be the probability that a true leader is misclassified, i.e. does not occupy a leadership position in any given year. It follows that the fraction $r p /(1-p)$ of nonleaders will occupy leadership positions each year. Assume that misclassification probabilities are independent across years. In a sample period of $n$ years (trials), the probability of never occupying a leadership position will be:

Prob (never in a leadership position) $\equiv \Pi(p, r, n)=p r^{n}-(1-p)\left(\frac{1-p-p r}{1-p}\right)^{n}$

We can then write:

Prob ("true" leader $\mid$ never in a leadership position) $\equiv \quad P^{0}(p, r, n)=\frac{p r^{n}}{\Pi(p, r, n)}$

Prob ("true" leader | in a leadership position at least once $) \equiv P^{1}(p, r, n)=\frac{p\left(1-r^{n}\right)}{1-\Pi(p, r, n)}$

The difference between (A3) and (A2), multiplied by the wage effect of being a "true" leader, is the expected value of the coefficient on an indicator variable for occupying a leadership role at least once during a period of $n$ years.

Given information on $p$ (according to the above definitions this just equals the fraction of the population who occupy a leadership role in a one-year sample) and an assumption about $r$, equations (A2) and (A3) allow us to calculate by how much we would expect the coefficient on occupying a leadership position to change if we used a three-year, rather than a one-year window period.

The results of this exercise are given in parts (a) and (b) of Table A1, for the NLS72 and HSB datasets respectively. Throughout Table A1, we define occupying a leadership position as being both captain and president, as this is our main focus in the paper. Wage coefficients are taken from the most highly parameterized specifications in Table 3 (columns 4, 8 and 12), and means from Table 1. To see how the simulations work, consider first the NLS72 calculations, say for $r=.1$. When 5.8 of the population are "true" leaders and the misclassification probability is ten percent, 7.5 percent of the population will occupy a leadership position at least once in three years (this is just one minus expression (A1) with $n=3$ ). The ratio of a three-year to a one-year leadership coefficient is given by $\left[P^{1}(p, r, 3)-P^{0}(p, r, 3)\right] /\left[P^{1}(p, r, 1)-P^{0}(p, r, 1)\right]$, or 862 . Thus, if a regression were run using a three-year definition of leadership in the HSB data, we should expect to see a coefficient of $.142 \times .862=.122$ (.142 is taken from column 8 of Table 3 ). Finally, note that under these assumptions we can also calculate the wage effect of "true" leadership which is consistent with the observed one-year coefficient of .142; it equals .159.

Now consider what happens as measurement error, $r$, rises above 0.1 . The true leadership effect that is consistent with the one-year regression coefficient of .142 increases, achieving implausibly high levels of $94 \log$ points when $r$ reaches 0.8 (when almost all true leaders are misclassified). Most importantly, however, because measurement error biases both 
the one-and three-year estimated coefficients downward (and because the relative bias in column 2 is U-shaped in $r$ ) the three-year coefficient implied by these assumptions is never less than three quarters of the one-year coefficient. The very lowest level of a three-year coefficient that is consistent with our NLS72 one-year coefficient of .142 is .108, corresponding to a

misclassification rate of 40 percent. This estimate still greatly exceeds the three-year leadershipwage coefficient in Talent (.046 in column 4 of Table 3). We conclude that, no matter what the amount of misclassification, the difference in observation window periods between Talent and NLS72 cannot explain the increase in the leadership wage effect between these two surveys.

Part b of Table A1 performs exactly the same exercise for HSB, using the mean percent "both" of .119 from Table 1 and the estimated one-year wage coefficient of .244 from column 12 of Table 3. By the same reasoning, the lowest three-year leadership coefficient that is consistent with HSB's one-year coefficient of .244 is .194 (corresponding to a misclassification probability of .3). This estimate is also much higher than the the three-year Talent coefficient of .046.

Part (c) of Table A1 performs the above analysis in reverse for the Talent data set. For differing assumed values of the misclassification probability $r$, Table 1 calculates the fraction of respondents (21.2 percent of whom occupied a leadership position at least once during a threeyear window), who would occupy such a position in data generated from just a one-year window. As one would expect, this falls as $r$ rises. Next, we calculate what the one-year leadership coefficient would be given the three-year estimate of .046 plus the assumed level of noise. This is never more than 26 percent higher, i.e. never greater than .058. This number is far below the one-year coefficients in NLS72 and Talent, again confirming our result that the use of a threeyear observation window cannot explain the difference between the Talent and the later results. Interestingly, the estimate of a three-year coefficient of .058 in Talent again corresponds to $r=$ .3. At $r=.3$, our estimated "true" leadership effects (adjusted for misclassification error) are $.088, .208$, and .370 in 1971 (Talent), 1986 (NLS72) and 1991 (HSB) respectively. 
Table A1: Simulated Effects of Measurement Error and Length of Observation Window on Estimated Leadership Coefficients.

(1)

(a) NLS72

$r$
0
0.1
0.2
0.3
0.4
0.5
0.6
0.7
0.8
0.9

(b) HSB

\section{$r$}

0

0.1

0.2

0.3

0.4

0.5

0.6

0.7

0.8

0.9

(c)Talent

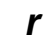

0

0.1

0.2

0.3

0.4

0.5

0.6

0.7

0.8

0.9
Prob(captain at least once in 3 years)

0.058

0.075

0.092

0.108

0.122

0.135

0.146

0.155

0.161

0.164

Prob(captain at least once in 3 years)

0.119

0.154

0.188

0.219

0.247

0.271

0.291

0.305

0.314

0.316
(2)

Ratio of 3-year to
1-year coefficient
1.000
0.862
0.794
0.766
0.765
0.783
0.817
0.867
0.933
1.018

Ratio of 3-year to

1.000

0.862

0.794

0.766

0.765

0.783

0.817

1.018

Ratio of 3-year to 1-year coefficient

1.000

0.870

0.813

0.797

0.809

0.842

0.893

0.961

1.046

1.150
(3)

Implied 3-year
coefficient
0.142
0.122
0.113
0.109
0.109
0.111
0.116
0.123
0.133
0.145

(4)

$\begin{gathered}\text { True leadership } \\ \text { effect }\end{gathered}$
0.142
0.159
0.180
0.208
0.247
0.303
0.391
0.553
0.942
3.185

Implied 3-year
coefficient
0.244
0.212
0.198
0.194
0.197
0.205
0.218
0.234
0.255
0.281

Implied 3-year

0.244

0.212

0.194

0.197

0.205

0.234

0.281

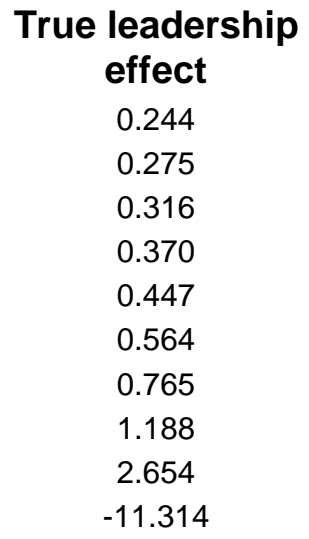

$\begin{array}{ccccc}\boldsymbol{r} & \begin{array}{c}\text { Prob(captain in } \\ \text { a single year) }\end{array} & \begin{array}{c}\text { Ratio of 1-year to } \\ \text { 3-year coefficient }\end{array} & \begin{array}{c}\text { Implied 1-year } \\ \text { coefficient }\end{array} & \begin{array}{c}\text { True leader- } \\ \text { ship effect }\end{array} \\ 0 & 0.212 & 1.000 & 0.046 & 0.046 \\ 0.1 & 0.164 & 1.140 & 0.052 & 0.060 \\ 0.2 & 0.135 & 1.222 & 0.056 & 0.073 \\ 0.3 & 0.115 & 1.258 & 0.058 & 0.088 \\ 0.4 & 0.102 & 1.256 & 0.058 & 0.104 \\ 0.5 & 0.092 & 1.222 & 0.056 & 0.126 \\ 0.6 & 0.085 & 1.178 & 0.054 & 0.158 \\ 0.7 & 0.081 & 1.111 & 0.051 & 0.215 \\ 0.8 & 0.078 & 1.033 & 0.048 & 0.359 \\ 0.9 & 0.076 & 0.948 & 0.044 & 1.679\end{array}$




\section{Appendix 2: Derivation of Likelihood for Endogenous-Leadership Model}

Suppose that individual $i$ occupies a high-school leadership position $\left(L_{i}=1\right)$ iff:

$Z_{i} \delta+\mu_{i}>0$

Let individual $i$ 's log wage be given by:

$w_{i}=X_{i} \beta+\mathcal{L}_{i}+\varepsilon_{i}$

Finally, let $\mu_{i}$ and $\varepsilon_{i}$ be joint normally distributed with mean zero, $\sigma_{\mu}=1$, and

correlation coefficient $\rho$.

Now consider an individual who is a leader. The likelihood of this observation can be written:

$\operatorname{Pr}\left(w_{i}=X_{i} \beta+\gamma L_{i}+\varepsilon_{i}\right) \bullet \operatorname{Pr}\left(\mu_{i}>-Z_{i} \partial \mid w_{i}=X_{i} \beta+\gamma L_{i}+\varepsilon_{i}\right)$

or,

$\left(1 / \sigma_{\varepsilon}\right) \bullet \phi\left(W_{i}\right) \bullet\left[1-\Phi\left(\frac{-Z_{i} \partial-\rho W_{i}}{\sqrt{1-\rho^{2}}}\right)\right]$

where $W_{i}=\frac{X_{i} \beta+\gamma L_{i}+\varepsilon_{i}}{\sigma_{\varepsilon}}$. Similarly, the likelihood of a nonleader observation is:

$\left(1 / \sigma_{\varepsilon}\right) \bullet \phi\left(W_{i}\right) \bullet \Phi\left(\frac{-Z_{i} \partial-\rho W_{i}}{\sqrt{1-\rho^{2}}}\right)$.

We then maximize the overall likelihood function, which is a product of terms like (4) and (5), with respect to the vectors $\delta$ and $\beta$, and the scalars $\gamma, \sigma_{\varepsilon}$ and $\rho$. 


\section{References}

Anderson, Deborah J. “'If You Let me Play': The Effects of Participation in High School Athletics on Students' Behavior and Economic Success”. Unpublished paper, Cornell University and University of New Mexico, February 2000.

Autor, D., F. Levy, and R. Murnane, “The Skill Content of Recent Technological Change: An Empirical Exploration” NBER Working Paper No. W8337 (June 2001).

Averett, Susan and Sanders Korenman. "The Economic Reality of The Beauty Myth" Journal of Human Resources 31(2) (Spring 1996): 304-30.

Barron, J. M., B. Ewing, and G. Waddell, "The Effects of High School Athletic Participation on Education and Labor Market Outcomes". Review of Economics and Statistics, August 2000, 82(3), pp. 1-13.

Biddle, Jeff E. and Daniel S. Hamermesh "Beauty, Productivity, and Discrimination: Lawyers' Looks and Lucre" Journal of Labor Economics16(1) (January 1998): 172-201

Bowles, S., H. Gintis, and M. Osborne, "The Determinants of Earnings: Skills, Preferences and Schooling”. Unpublished manuscript, University of Massachusetts, August 2000.

Camp, William, "Participation in Student Activities and Achievement: A Covariance Structural Analysis, Journal of Educatoinal Research, 1990, 83: 272-278.

Card, D. and T. Lemieux, "Can Falling Supply Explain the Rising Return to College for Younger Men? A Cohort-Based Analysis" Quarterly Journal of Economics 116(2) (May 2001): 705-46.

Cawley, J., K. Conneely, J. Heckman and E. Vyactil, "Cognitive Ability, Wages and Meritocracy". in B. Devlin, S. Fienberg, D. Resnick, and K. Roeder, eds., Intelligence, Genes and Success: Scientists Respond to the Bell Curve. New York: Springer-Verlag, 1997. pp. 179-192

Cawley, J., J. Heckman, and E. Vytlacil. "Three Observations on Wages and Measured Cognitive Ability”. Labour Economics 8 (2001): 419-442.

Coleman, M. and T. DeLeire. “An Economic Model of Teenagers' Locus of Control and High School Graduation Decisions". Unpublished manuscript, Irving B. Harris School of Public Policy Studies, University of Chicago, July 2000.

Eide, Eric and Nick Ronan. "Is Participation in High School Athletics an Investment or Consumption Good? Evidence from High School and Beyond" unpublished manuscript, Brigham Young University, Feb. 2000.

Farber, H. and R. Gibbons. "Learning and Wage Dynamics". Quarterly Journal of Economics 111(4) (November 1996): 1007-1048.

Gardner, Howard. Frames of Mind : The Theory of Multiple Intelligences New York : Basic Books, 1983. 
Gerber, Susan. "Extracurricular Activities and Academic Achievement." Journal of Research and Development in Education. 1996, 30(1):42-50.

Goldsmith, Arthur H; J. R. Veum, and W. Darity, Jr. "The Impact of Psychological and Human Capital on Wages" Economic Inquiry 35 (4), (Oct 1997):815-829.

Goldsmith, Arthur H; J. R. Veum, and W. Darity, Jr. "Motivation and Labor Market Outcomes". Unpublished manuscript, Washington and Lee University, 2000.

Goleman, D. Emotional Intelligence: Why it can matter more than IQ. New York: Bantam, 1997.

Grogger, J. and E. Eide, "Changes in College Skills and the Rise in the College Wage Premium," Journal of Human Resources, 30(2), (1995):280-310.

Hamermesh, D. and J. Biddle. "Beauty and the Labor Market". American Economic Review 84(5) (December 1994): 1174-94.

Hanks, Michael and Bruce Eckland, "Athletics and Social Participation in the Educational Attainment Process.” Sociology of Education, 1976, 49:271-294.

Herrnstein, R. and C. Murray. The Bell Curve: Intelligence and Class Structure in American Life. New York: The Free Press, 1994.

Juhn, C., K. Murphy and B. Pierce. "Wage Inequality and the Rise in Returns to Skill" Journal of Political Economy 101(3) (June 1993): 410-42.

Landers, Daniel and Donna Landers, "Socialization via Interscholastic Athletics: Its Effects on Delinquency," Sociology of Education, 1978, 51:299-303.

Lindbeck, A. and D. Snower. "Multitask Learning and the Reorganization of Work: From Tayloristic to Holistic Organization" Journal of Labor Economics 18(3), (July 2000): $353-76$

Melamed, T. and N. Bozionelos. "Managerial Promotion and Height". Psychological Reports 71 (1992): 587-593.

Morse, Jodie, “In or Out: Inside College Admissions," Time Magazine, November 28, 2001.

Murphy, K. J. "Executive Compensation", in Ashenfelter, O. and D. Card, eds. $\underline{\text { Handbook of }}$ labor economics. Volume 3B. Amsterdam: North-Holland (1999): 2485-2563.

National Association of Colleges and Employers, "Ideal Candidate Has Top-Notch Interpersonal Skills, Say Employers”. January 18, 2000.

Osborne, M. "Personality and Labor Market Success". Unpublished manuscript, University of Massachusetts, Amherst, October 1999.

Otto, Luther, "Extracurricular Activities in the Educational Attainment Process." Rural Sociology, 1975, 4-:162-176. 
Otto, Luther, "Extracurricular Activities and Aspirations in the Status Attainment Process." Rural Sociology, 1976, 41:217-233.

Otto, Luther and Duane Alwin, "Athletics, Aspirations, and Attainments." Sociology of Education, 1977, 42:102-113.

Rosen, S. "Authority, Control, and the Distribution of Earnings" Bell Journal of Economics 13(2) (Autumn 1982): 311-23.

Roy, A. D. "Some Thoughts on the Distribution of Earnings", Oxford Economic Papers, 1951.

Scannell, Kara. "The Few. The Proud. The... M.B.A.s (?!)”. The Wall Street Journal, June 5, 2001. p. C1.

Spady, W. "Lament for the Letterman: Effects of Peer Status and Extracurricular Activities on Goals and Achievement," American Journal of Sociology, 1970, 75:680-701.

Stephenson, Betsey. "Evidence on the Effects of Sports Participation: Examining the Impact of Title IX”. Unpublished paper, Harvard University, November 22, 2000.

Sternberg, Robert. The Triarchic Mind: A New Theory of Human Intelligence. New York: Viking Penguin, 1988. 
Table 1: Sample Means

\begin{tabular}{|c|c|c|c|c|}
\hline & $\begin{array}{l}\text { Talent, grades } 10- \\
12 \text { (High School } \\
1960, \\
\text { Earnings 1971-73) }\end{array}$ & $\begin{array}{l}\text { Talent, grade } 12 \\
\text { only (High School } \\
\text { Seniors 1960, } \\
\text { Earnings 1971) }\end{array}$ & $\begin{array}{l}\text { NLS72 (High } \\
\text { School Seniors } \\
\text { 1972, } \\
\text { Earnings 1986) }\end{array}$ & $\begin{array}{l}\text { HSB (High } \\
\text { School Seniors } \\
\text { 1982, } \\
\text { Earnings 1991) }\end{array}$ \\
\hline \multicolumn{5}{|l|}{ Earnings: } \\
\hline Hourly Earnings & $\$ 5.30$ & & $\$ 13.00$ & \\
\hline Annual Earnings & & $\$ 11,000$ & & $\$ 26,200$ \\
\hline \multicolumn{5}{|l|}{ Leadership: $^{1}$} \\
\hline Both Captain \& President & 0.218 & 0.212 & 0.058 & 0.119 \\
\hline Captain only & 0.138 & 0.137 & 0.103 & 0.137 \\
\hline President only & 0.221 & 0.225 & 0.160 & 0.233 \\
\hline \multicolumn{5}{|l|}{ Membership: ${ }^{1}$} \\
\hline Both on team \& in club & 0.776 & 0.778 & 0.442 & 0.506 \\
\hline On team only & 0.027 & 0.019 & 0.163 & 0.108 \\
\hline In club only & 0.179 & 0.189 & 0.233 & 0.258 \\
\hline Math Score (percentile/100) & .487 & .482 & .502 & .500 \\
\hline \multicolumn{5}{|l|}{ Educational Attainment: } \\
\hline HS only & 0.329 & 0.342 & 0.319 & 0.259 \\
\hline Some College & 0.278 & 0.263 & 0.290 & 0.373 \\
\hline College Degree or higher & 0.392 & 0.395 & 0.391 & 0.369 \\
\hline \multicolumn{5}{|l|}{ Parents' Education: } \\
\hline High School $^{2}$ & 0.548 & 0.556 & 0.677 & 0.635 \\
\hline College Degree $^{3}$ & 0.195 & 0.187 & 0.309 & 0.289 \\
\hline $\begin{array}{l}\text { Number of Schools } \\
\text { Represented }\end{array}$ & 1005 & 761 & 805 & 661 \\
\hline Sample Size & 24,041 & 8,269 & 2,801 & 2,098 \\
\hline
\end{tabular}

Notes: In all cases the sample includes only white men.

1. Talent Leadership/Membership refers to any time in the past three years; NLS and HSB to the last year only.

2. At least one parent is a high school graduate, but neither is a college graduate.

3. At least one parent is a college graduate. 
Table 2: Effects of High School Leadership Activities on Log (hourly earnings) eleven years later, Project Talent Data.

\begin{tabular}{|c|c|c|c|c|c|c|c|c|}
\hline & $(1)$ & $(2)$ & $(3)$ & (4) & $(5)$ & $(6)$ & $(7)$ & $(8)$ \\
\hline \multicolumn{9}{|l|}{ Leader: ${ }^{1}$} \\
\hline $\begin{array}{c}\text { Both Captain \& } \\
\text { President }\end{array}$ & $\begin{array}{l}0.077 \\
(0.013) * *\end{array}$ & $\begin{array}{l}0.054 \\
(0.014) * *\end{array}$ & $\begin{array}{l}0.053 \\
(0.014) * *\end{array}$ & $\begin{array}{l}0.042 \\
(0.014) * *\end{array}$ & $\begin{array}{l}0.073 \\
(0.012)^{* *}\end{array}$ & $\begin{array}{l}0.051 \\
(0.012)^{* *}\end{array}$ & $\begin{array}{l}0.049 \\
(0.012) * *\end{array}$ & $\begin{array}{l}0.038 \\
(0.012) * * \\
\end{array}$ \\
\hline Captain only & $\begin{array}{l}0.047 \\
(0.015)^{* *}\end{array}$ & $\begin{array}{l}0.030 \\
(0.015)\end{array}$ & $\begin{array}{l}0.030 \\
(0.015)\end{array}$ & $\begin{array}{l}0.029 \\
(0.015)\end{array}$ & $\begin{array}{l}0.052 \\
(0.013) * *\end{array}$ & $\begin{array}{l}0.035 \\
(0.013) * *\end{array}$ & $\begin{array}{l}0.036 \\
(0.013) * *\end{array}$ & $\begin{array}{l}0.034 \\
(0.013) * *\end{array}$ \\
\hline President only & $\begin{array}{l}0.054 \\
(0.012)^{* *}\end{array}$ & $\begin{array}{l}0.038 \\
(0.013) * *\end{array}$ & $\begin{array}{l}0.024 \\
(0.013)\end{array}$ & $\begin{array}{l}0.014 \\
(0.013) \\
\end{array}$ & $\begin{array}{l}0.048 \\
(0.011)^{* *}\end{array}$ & $\begin{array}{l}0.032 \\
(0.011)^{* *}\end{array}$ & $\begin{array}{l}0.019 \\
(0.011)\end{array}$ & $\begin{array}{l}0.010 \\
(0.011)\end{array}$ \\
\hline \multicolumn{9}{|l|}{ Member: ${ }^{1}$} \\
\hline $\begin{array}{l}\text { Both on team \& } \\
\text { in club }\end{array}$ & & $\begin{array}{l}0.082 \\
(0.027)^{* *}\end{array}$ & $\begin{array}{l}0.051 \\
(0.027)\end{array}$ & $\begin{array}{l}0.037 \\
(0.026)\end{array}$ & & $\begin{array}{l}0.097 \\
(0.025)^{* *}\end{array}$ & $\begin{array}{l}0.070 \\
(0.025)^{* *}\end{array}$ & $\begin{array}{l}0.056 \\
(0.025)^{*}\end{array}$ \\
\hline On team only & & $\begin{array}{l}0.076 \\
(0.039)^{*}\end{array}$ & $\begin{array}{l}0.058 \\
(0.038)\end{array}$ & $\begin{array}{l}0.058 \\
(0.037)\end{array}$ & & $\begin{array}{l}0.081 \\
(0.035)^{*}\end{array}$ & $\begin{array}{l}0.063 \\
(0.034)\end{array}$ & $\begin{array}{l}0.062 \\
(0.034)\end{array}$ \\
\hline In club only & & $\begin{array}{l}0.013 \\
(0.029)\end{array}$ & $\begin{array}{l}-0.011 \\
(0.028)\end{array}$ & $\begin{array}{l}-0.021 \\
(0.028)\end{array}$ & & $\begin{array}{l}0.028 \\
(0.027)\end{array}$ & $\begin{array}{l}0.005 \\
(0.026)\end{array}$ & $\begin{array}{l}-0.005 \\
(0.026)\end{array}$ \\
\hline Math Score: & & & $\begin{array}{l}0.230 \\
(0.019)^{* *}\end{array}$ & $\begin{array}{l}0.139 \\
(0.021)^{* *}\end{array}$ & & & $\begin{array}{l}0.213 \\
(0.017)^{* *}\end{array}$ & $\begin{array}{l}0.131 \\
(0.019) * *\end{array}$ \\
\hline \multicolumn{9}{|l|}{ Parents' Education: } \\
\hline High School $^{2}$ & & $\begin{array}{l}0.049 \\
(0.012)^{* *}\end{array}$ & $\begin{array}{l}0.026 \\
(0.012)^{*}\end{array}$ & $\begin{array}{l}0.015 \\
(0.012) \\
\end{array}$ & & $\begin{array}{l}0.040 \\
(0.011)^{* *}\end{array}$ & $\begin{array}{l}0.021 \\
(0.011)\end{array}$ & $\begin{array}{l}0.012 \\
(0.011)\end{array}$ \\
\hline College Degree $^{3}$ & & 0.067 & 0.020 & -0.006 & & 0.052 & 0.019 & -0.003 \\
\hline & & $(0.014)^{* *}$ & $(0.014)$ & $(0.015)$ & & $(0.014) * *$ & $(0.014)$ & $(0.014)$ \\
\hline \multicolumn{9}{|c|}{ Educational Attainment: } \\
\hline $\begin{array}{l}\text { Some } \\
\text { College }\end{array}$ & & & & $\begin{array}{l}0.066 \\
(0.013) * *\end{array}$ & & & & $\begin{array}{l}0.049 \\
(0.012)^{* *}\end{array}$ \\
\hline $\begin{array}{l}\text { College Degree } \\
\text { or Higher }\end{array}$ & & & & $\begin{array}{l}0.147 \\
(0.015)^{* *}\end{array}$ & & & & $\begin{array}{l}0.134 \\
(0.013) * *\end{array}$ \\
\hline $\begin{array}{l}\text { State Controls? } \\
\text { School Controls? }\end{array}$ & $\begin{array}{l}\text { Yes } \\
\text { No }\end{array}$ & $\begin{array}{l}\text { Yes } \\
\text { No }\end{array}$ & $\begin{array}{l}\text { Yes } \\
\text { No }\end{array}$ & $\begin{array}{l}\text { Yes } \\
\text { No }\end{array}$ & $\begin{array}{l}\text { No } \\
\text { Yes }\end{array}$ & $\begin{array}{l}\text { No } \\
\text { Yes }\end{array}$ & $\begin{array}{l}\text { No } \\
\text { Yes }\end{array}$ & $\begin{array}{l}\text { No } \\
\text { Yes }\end{array}$ \\
\hline Observations & 24041 & 24041 & 24041 & 24041 & 24041 & 24041 & 24041 & 24041 \\
\hline R-squared (adj.) & .061 & .069 & .091 & .101 & .162 & .167 & .184 & .195 \\
\hline
\end{tabular}

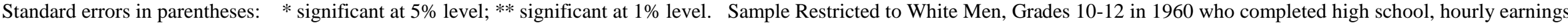
between \$1 and \$50. All regressions include controls for grade in 1960 (cohort). Columns 2-4 and 6-8 include an indicator for missing parental education. Columns 4 and 8 include an indicator for missing own educational attainment.

1. Talent Leadership/Membership refers to any time in the past three years.

2. At least one parent is a high school graduate, but neither is a college graduate.

3. At least one parent is a college graduate. 
Table 3. Effects of High School Leadership Activities on Log (earnings), Various Data Sources and Dependent Variables

\begin{tabular}{|c|c|c|c|c|c|c|c|c|c|c|c|c|}
\hline & \multicolumn{4}{|c|}{$\begin{array}{l}\text { Talent: Log of annual earnings in } 1971 \\
\text { (11years after high school). }\end{array}$} & \multicolumn{4}{|c|}{$\begin{array}{l}\text { NLS 72: Log of hourly earnings in } 1986 \\
\text { (13years after high school) }^{5}\end{array}$} & \multicolumn{4}{|c|}{$\begin{array}{l}\text { HSB: Log of annual earnings in } 1992 \\
(9 \text { years after high school })^{6}\end{array}$} \\
\hline & (1) & (2) & (3) & (4) & (5) & (6) & (7) & (8) & (9) & (10) & (11) & (12) \\
\hline \multicolumn{13}{|l|}{ Leadership: ${ }^{1}$} \\
\hline $\begin{array}{l}\text { Both Captain } \\
\& \text { president }\end{array}$ & $\begin{array}{l}0.091 \\
(0.023)^{* *}\end{array}$ & $\begin{array}{l}0.061 \\
(0.023)^{* *}\end{array}$ & $\begin{array}{l}0.059 \\
(0.023)^{*}\end{array}$ & $\begin{array}{l}0.046 \\
(0.022) *\end{array}$ & $\begin{array}{l}0.221 \\
(0.052)^{* * *}\end{array}$ & $\begin{array}{l}0.167 \\
(0.055) * *\end{array}$ & $\begin{array}{l}0.147 \\
(0.054) * *\end{array}$ & $\begin{array}{l}0.142 \\
(0.054) * *\end{array}$ & $\begin{array}{l}0.291 \\
(0.058)^{* *}\end{array}$ & $\begin{array}{l}0.268 \\
(0.062)^{* *}\end{array}$ & $\begin{array}{l}0.258 \\
(0.062)^{* *}\end{array}$ & $\begin{array}{l}0.244 \\
(0.063)^{* *}\end{array}$ \\
\hline Captain only & $\begin{array}{l}0.039 \\
(0.020)\end{array}$ & $\begin{array}{l}0.009 \\
(0.020)\end{array}$ & $\begin{array}{l}0.010 \\
(0.020)\end{array}$ & $\begin{array}{l}0.005 \\
(0.020)\end{array}$ & $\begin{array}{l}0.094 \\
(0.040)^{*}\end{array}$ & $\begin{array}{l}0.063 \\
(0.042)\end{array}$ & $\begin{array}{l}0.057 \\
(0.042)\end{array}$ & $\begin{array}{l}0.050 \\
(0.042)\end{array}$ & $\begin{array}{l}0.186 \\
(0.048)^{* *}\end{array}$ & $\begin{array}{l}0.161 \\
(0.051)^{* *}\end{array}$ & $\begin{array}{l}0.160 \\
(0.051)^{* *}\end{array}$ & $\begin{array}{l}0.150 \\
(0.051)^{* *}\end{array}$ \\
\hline President only & $\begin{array}{l}0.059 \\
(0.018)^{* *}\end{array}$ & $\begin{array}{l}0.032 \\
(0.017)\end{array}$ & $\begin{array}{l}0.020 \\
(0.017)\end{array}$ & $\begin{array}{l}0.012 \\
(0.017)\end{array}$ & $\begin{array}{l}0.089 \\
(0.032)^{* *}\end{array}$ & $\begin{array}{l}0.050 \\
(0.034)\end{array}$ & $\begin{array}{l}0.031 \\
(0.033)\end{array}$ & $\begin{array}{l}0.019 \\
(0.033)\end{array}$ & $\begin{array}{l}0.144 \\
(0.038)^{* *}\end{array}$ & $\begin{array}{l}0.161 \\
(0.041)^{* *}\end{array}$ & $\begin{array}{l}0.153 \\
(0.042)^{* *}\end{array}$ & $\begin{array}{l}0.147 \\
(0.043)^{* *}\end{array}$ \\
\hline \multicolumn{13}{|l|}{ Membership: ${ }^{1}$} \\
\hline $\begin{array}{l}\text { Both on team } \\
\& \text { in club }\end{array}$ & & $\begin{array}{l}0.133 \\
(0.036) * *\end{array}$ & $\begin{array}{l}0.109 \\
(0.036)^{* *}\end{array}$ & $\begin{array}{l}0.098 \\
(0.036) * *\end{array}$ & & $\begin{array}{l}0.114 \\
(0.038) * *\end{array}$ & $\begin{array}{l}0.092 \\
(0.037)^{*}\end{array}$ & $\begin{array}{l}0.083 \\
(0.038)^{*}\end{array}$ & & $\begin{array}{l}0.001 \\
(0.055)\end{array}$ & $\begin{array}{l}-0.023 \\
(0.054)\end{array}$ & $\begin{array}{l}-0.031 \\
(0.055)\end{array}$ \\
\hline On team only & & $\begin{array}{l}0.074 \\
(0.052)\end{array}$ & $\begin{array}{l}0.067 \\
(0.051)\end{array}$ & $\begin{array}{l}0.074 \\
(0.051)\end{array}$ & & $\begin{array}{l}0.078 \\
(0.041)\end{array}$ & $\begin{array}{l}0.066 \\
(0.040)\end{array}$ & $\begin{array}{l}0.059 \\
(0.040)\end{array}$ & & $\begin{array}{l}0.027 \\
(0.070)\end{array}$ & $\begin{array}{l}0.018 \\
(0.069)\end{array}$ & $\begin{array}{l}0.020 \\
(0.070)\end{array}$ \\
\hline In club only & & $\begin{array}{l}0.040 \\
(0.039)\end{array}$ & $\begin{array}{l}0.020 \\
(0.039)\end{array}$ & $\begin{array}{l}0.012 \\
(0.038)\end{array}$ & & $\begin{array}{l}0.090 \\
(0.039)^{*}\end{array}$ & $\begin{array}{l}0.085 \\
(0.038)^{*}\end{array}$ & $\begin{array}{l}0.081 \\
(0.039)^{*}\end{array}$ & & $\begin{array}{l}-0.075 \\
(0.058)\end{array}$ & $\begin{array}{l}-0.085 \\
(0.057)\end{array}$ & $\begin{array}{l}-0.085 \\
(0.057)\end{array}$ \\
\hline Math Score: & & & $\begin{array}{l}0.237 \\
(0.027)^{* *}\end{array}$ & $\begin{array}{l}0.160 \\
(0.028)^{* *}\end{array}$ & & & $\begin{array}{l}0.283 \\
(0.043)^{* * *}\end{array}$ & $\begin{array}{l}0.237 \\
(0.047)^{* *}\end{array}$ & & & $\begin{array}{l}0.210 \\
(0.058)^{* *}\end{array}$ & $\begin{array}{l}0.131 \\
(0.063)^{*}\end{array}$ \\
\hline \multicolumn{13}{|l|}{ Parent Education: } \\
\hline High School $^{2}$ & & $\begin{array}{l}0.051 \\
(0.016) * *\end{array}$ & $\begin{array}{l}0.028 \\
(0.016)\end{array}$ & $\begin{array}{l}0.016 \\
(0.016)\end{array}$ & & $\begin{array}{l}0.113 \\
(0.080)\end{array}$ & $\begin{array}{l}0.068 \\
(0.079)\end{array}$ & $\begin{array}{l}0.062 \\
(0.078)\end{array}$ & & $\begin{array}{l}-0.066 \\
(0.063)\end{array}$ & $\begin{array}{l}-0.077 \\
(0.061)\end{array}$ & $\begin{array}{l}-0.091 \\
(0.062)\end{array}$ \\
\hline College Degree $^{3}$ & & $\begin{array}{l}0.100 \\
(0.021)^{* *}\end{array}$ & $\begin{array}{l}0.059 \\
(0.021)^{* *}\end{array}$ & $\begin{array}{l}0.038 \\
(0.022) \\
\end{array}$ & & $\begin{array}{l}0.161 \\
(0.083)\end{array}$ & $\begin{array}{l}0.091 \\
(0.082)\end{array}$ & $\begin{array}{l}0.073 \\
(0.082) \\
\end{array}$ & & $\begin{array}{l}-0.051 \\
(0.068) \\
\end{array}$ & $\begin{array}{l}-0.076 \\
(0.067) \\
\end{array}$ & $\begin{array}{l}-0.103 \\
(0.068) \\
\end{array}$ \\
\hline \multicolumn{13}{|l|}{ Own Education: } \\
\hline $\begin{array}{l}\text { Some } \\
\text { College }\end{array}$ & & & & $\begin{array}{l}0.021 \\
(0.021)\end{array}$ & & & & $\begin{array}{l}-0.021 \\
(0.031)\end{array}$ & & & & $\begin{array}{l}-0.005 \\
(0.045)\end{array}$ \\
\hline $\begin{array}{l}\text { College Degree } \\
\text { or higher }\end{array}$ & & & & $\begin{array}{l}0.113 \\
(0.020)^{* *}\end{array}$ & & & & $\begin{array}{l}0.076 \\
(0.034)^{*}\end{array}$ & & & & $\begin{array}{l}0.119 \\
(0.052) *\end{array}$ \\
\hline Observations & 8269 & 8269 & 8269 & 8269 & 2801 & 2801 & 2801 & 2801 & 2098 & 2098 & 2098 & 2098 \\
\hline R-squared (adj) & 0.208 & 0.224 & 0.244 & 0.253 & .063 & .071 & .094 & .099 & .216 & .218 & .227 & .233 \\
\hline
\end{tabular}

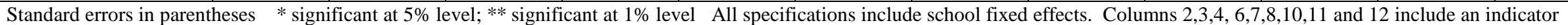

for missing parental education. Columns 4, 8, and 12 include an indicator for missing own education. All samples restricted to white men only.

1. Talent Leadership/Membership refers to any time in the past three years; NLS and HSB to the last year only.

2. At least one parent is a high school graduate, but neither is a college graduate.

3. At least one parent is a college graduate.

4. Grade 12 in 1960 who completed high school, Annual earnings between $\$ 735$ and $\$ 29,400$ (equivalent to $\$ 2500-100,000$ in 1991 dollars).

5. Grade 12 in 1972, Hourly earnings between 2.70 and 135 in 1986 (equivalent to $\$ 1-\$ 50$ in 1960 dollars).

6. Sophomore cohort, who eventually completed high school, Annual Earnings between $\$ 2500 \& \$ 100,000$ in 1991 
Table 4: Effects of Alternative High-School Leadership Measures on Adult Earnings, Project Talent and HSB Data.

\begin{tabular}{|c|c|c|c|c|c|c|c|c|}
\hline & \multicolumn{4}{|c|}{ Project Talent: log hourly wages, 11 years later } & \multicolumn{4}{|c|}{ HSB: log annual earnings, 9 years later } \\
\hline $\begin{array}{l}\text { Leadership score (percentiles in } \\
\text { distribution): }\end{array}$ & (1) & (2) & (3) & (4) & (5) & (6) & (7) & $(8)$ \\
\hline $\begin{array}{l}5 \text { (top 3\% in Talent) } \\
\text { (top 3\% in HSB) }\end{array}$ & $\begin{array}{l}0.221 \\
(0.027)^{* *}\end{array}$ & $\begin{array}{l}0.214 \\
(0.027)^{* *}\end{array}$ & $\begin{array}{l}0.182 \\
(0.028) * *\end{array}$ & $\begin{array}{l}0.162 \\
(0.027) * *\end{array}$ & $\begin{array}{l}0.355 \\
(0.099) * *\end{array}$ & $\begin{array}{l}0.346 \\
(0.100)^{* *}\end{array}$ & $\begin{array}{l}0.315 \\
(0.0996) * *\end{array}$ & $\begin{array}{l}0.288 \\
(0.100) * *\end{array}$ \\
\hline $\begin{array}{c}4\left(90^{\text {th }}-97^{\text {th }} \text { percentile in Talent }\right) \\
\left(87^{\text {th }}-97^{\text {th }} \text { percentile in HSB }\right)\end{array}$ & $\begin{array}{l}0.124 \\
(0.018) * *\end{array}$ & $\begin{array}{l}0.118 \\
(0.018)^{* *}\end{array}$ & $\begin{array}{l}0.098 \\
(0.018)^{* *}\end{array}$ & $\begin{array}{l}0.079 \\
(0.018)^{* *}\end{array}$ & $\begin{array}{l}0.233 \\
(0.054)^{* *}\end{array}$ & $\begin{array}{l}0.231 \\
(0.055)^{* *}\end{array}$ & $\begin{array}{l}0.213 \\
(0.056) * *\end{array}$ & $\begin{array}{l}0.184 \\
(0.057)^{* *}\end{array}$ \\
\hline $\begin{array}{c}3\left(81^{\text {st }}-90^{\text {th }} \text { percentile in Talent }\right) \\
\left(75^{\text {th }}-87^{\text {th }} \text { percentile in HSB }\right)\end{array}$ & $\begin{array}{l}0.085 \\
(0.014)^{* *}\end{array}$ & $\begin{array}{l}0.082 \\
(0.014)^{* *}\end{array}$ & $\begin{array}{l}0.067 \\
(0.014) * *\end{array}$ & $\begin{array}{l}0.055 \\
(0.014)^{* *}\end{array}$ & $\begin{array}{l}0.164 \\
(0.058)^{* *}\end{array}$ & $\begin{array}{l}0.162 \\
(0.058) * *\end{array}$ & $\begin{array}{l}0.146 \\
(0.058) *\end{array}$ & $\begin{array}{l}0.134 \\
(0.058) *\end{array}$ \\
\hline $\begin{array}{c}2\left(65^{\text {th }}-81^{\text {st }} \text { percentile in Talent }\right) \\
\left(57^{\text {th }}-75^{\text {th }} \text { percentile in HSB }\right)\end{array}$ & $\begin{array}{l}0.056 \\
(0.012)^{* *}\end{array}$ & $\begin{array}{l}0.053 \\
(0.012)^{* *}\end{array}$ & $\begin{array}{l}0.047 \\
(0.012)^{* *}\end{array}$ & $\begin{array}{l}0.038 \\
(0.012)^{* *}\end{array}$ & $\begin{array}{l}0.164 \\
(0.049)^{* *}\end{array}$ & $\begin{array}{l}0.164 \\
(0.05)^{* *}\end{array}$ & $\begin{array}{l}0.146 \\
(0.050) * *\end{array}$ & $\begin{array}{l}0.130 \\
(0.050)^{* *}\end{array}$ \\
\hline 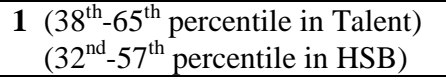 & $\begin{array}{l}0.047 \\
(0.010)^{* *}\end{array}$ & $\begin{array}{l}0.046 \\
(0.010)^{* *}\end{array}$ & $\begin{array}{l}0.041 \\
(0.010)^{* *}\end{array}$ & $\begin{array}{l}0.035 \\
(0.010)^{* *}\end{array}$ & $\begin{array}{l}0.041 \\
(0.040)\end{array}$ & $\begin{array}{l}0.042 \\
(0.040)\end{array}$ & $\begin{array}{l}0.0381 \\
(0.040)\end{array}$ & $\begin{array}{l}0.027 \\
(0.040)\end{array}$ \\
\hline Math Score: & & & $\begin{array}{l}0.196 \\
(0.016)^{* *}\end{array}$ & $\begin{array}{l}0.123 \\
(0.018)^{* *}\end{array}$ & & & $\begin{array}{l}0.200 \\
(0.058) * *\end{array}$ & $\begin{array}{l}0.124 \\
(0.063)^{*}\end{array}$ \\
\hline \multicolumn{9}{|l|}{ Parents' Education: } \\
\hline High School $^{1}$ & & $\begin{array}{l}0.042 \\
(0.010)^{* *}\end{array}$ & $\begin{array}{l}0.025 \\
(0.011)^{*}\end{array}$ & $\begin{array}{l}0.016 \\
(0.010)\end{array}$ & & $\begin{array}{l}-0.06328 \\
(0.0641) \\
\end{array}$ & $\begin{array}{l}-0.073 \\
(0.06212) \\
\end{array}$ & $\begin{array}{l}-0.084 \\
(0.063) \\
\end{array}$ \\
\hline College Degree $^{2}$ & & $\begin{array}{l}0.041 \\
(0.013) * *\end{array}$ & $\begin{array}{l}0.010 \\
(0.013) \\
\end{array}$ & $\begin{array}{l}-0.010 \\
(0.014) \\
\end{array}$ & & $\begin{array}{l}-0.05592 \\
(0.0701) \\
\end{array}$ & $\begin{array}{l}-0.0791 \\
(0.0685)\end{array}$ & $\begin{array}{l}-0.105 \\
(0.070) \\
\end{array}$ \\
\hline \multicolumn{9}{|l|}{ Own Education: } \\
\hline $\begin{array}{l}\text { Some } \\
\text { College }\end{array}$ & & & & $\begin{array}{l}0.042 \\
(0.011)^{* *}\end{array}$ & & & & $\begin{array}{l}0.005 \\
(0.043)\end{array}$ \\
\hline $\begin{array}{l}\text { College Degree } \\
\text { or Higher }\end{array}$ & & & & $\begin{array}{l}0.121 \\
(0.012)^{* *}\end{array}$ & & & & $\begin{array}{l}0.123 \\
(0.051)^{*}\end{array}$ \\
\hline Observations & 27413 & 27413 & 27413 & 27413 & 2129 & 2129 & 2129 & 2129 \\
\hline R-squared (adj.) & .164 & .166 & .180 & .191 & 0.204 & 0.204 & 0.213 & 0.219 \\
\hline
\end{tabular}

Standard errors in parentheses. * significant at $5 \%$ level; ** significant at $1 \%$ level

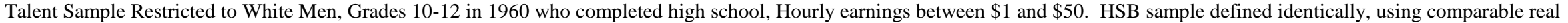
values for earnings, but for seniors only.

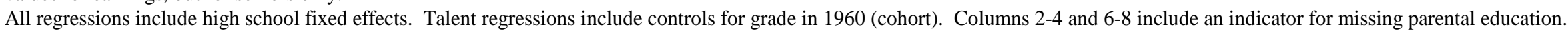
Columns 4 and 8 include an indicator for missing own educational attainment.

1. At least one parent is a high school graduate, but neither is a college graduate.

2. At least one parent is a college graduate. 
Table 5: Marginal Effects of Selected Leadership Measures on log (wages) within education and math test score groups: Project Talent Data.

\begin{tabular}{|c|c|c|c|c|c|c|c|}
\hline & \multicolumn{2}{|c|}{ Math Score: } & \multicolumn{2}{|c|}{ Own Education: } & \multicolumn{3}{|c|}{ Parent s' Education: } \\
\hline & $\begin{array}{c}\text { Below } 50^{\text {th }} \\
\text { percentile }\end{array}$ & $\begin{array}{r}50^{\text {th }} \text { percentile } \\
\text { or above }\end{array}$ & $\begin{array}{r}\text { Less Than } \\
\text { Bachelor's } \\
\text { Degree }\end{array}$ & $\begin{array}{r}\text { Bachelor's } \\
\text { Degree } \\
\text { or More }\end{array}$ & $\begin{array}{r}\text { Less Than } \\
\text { High School }\end{array}$ & $\begin{array}{r}\text { High } \\
\text { School }\end{array}$ & $\begin{array}{l}\text { College } \\
\text { Degree }\end{array}$ \\
\hline \multicolumn{8}{|l|}{ Leadership Activity } \\
\hline $\begin{array}{l}\text { Both Captain } \\
\text { and President }\end{array}$ & $\begin{array}{l}0.037 \\
(0.017)^{*} \\
\end{array}$ & $\begin{array}{l}0.038 \\
(0.015)^{*}\end{array}$ & \begin{tabular}{|l|}
0.037 \\
$(0.015)^{*}$
\end{tabular} & $\begin{array}{l}0.045 \\
(0.021)^{*}\end{array}$ & $\begin{array}{l}0.017 \\
(0.024)\end{array}$ & $\begin{array}{l}0.042 \\
(0.018)^{*}\end{array}$ & $\begin{array}{l}0.053 \\
(0.025)^{*}\end{array}$ \\
\hline Captain Only & $\begin{array}{l}0.034 \\
(0.017)^{*}\end{array}$ & $\begin{array}{l}0.035 \\
(0.017)^{*}\end{array}$ & $\begin{array}{l}0.054 \\
(0.017)^{* *}\end{array}$ & $\begin{array}{l}0.018 \\
(0.020)\end{array}$ & $\begin{array}{l}0.019 \\
(0.025)\end{array}$ & $\begin{array}{l}0.046 \\
(0.017)^{* *}\end{array}$ & $\begin{array}{l}0.010 \\
(0.026)\end{array}$ \\
\hline \multirow[t]{2}{*}{ President Only } & $\begin{array}{l}0.019 \\
(0.016)\end{array}$ & $\begin{array}{l}0.002 \\
(0.014)\end{array}$ & $\begin{array}{l}0.018 \\
(0.015)\end{array}$ & $\begin{array}{l}0.013 \\
(0.017)\end{array}$ & $\begin{array}{l}0.005 \\
(0.023)\end{array}$ & $\begin{array}{l}0.008 \\
(0.015)\end{array}$ & $\begin{array}{l}0.029 \\
(0.021)\end{array}$ \\
\hline & \multicolumn{2}{|c|}{$\mathrm{N}=24041$} & \multicolumn{2}{|c|}{$\mathrm{N}=21484$} & \multicolumn{3}{|c|}{$\mathrm{N}=22953$} \\
\hline \multicolumn{8}{|l|}{$\begin{array}{l}\text { Self-Assessed } \\
\text { Leadership } \\
\end{array}$} \\
\hline $\begin{array}{l}\text { Silead } \\
\text { (standardized) }\end{array}$ & $\begin{array}{l}0.029 \\
(0.008)^{* *}\end{array}$ & $\begin{array}{l}0.025 \\
(0.005)^{* *}\end{array}$ & \begin{tabular}{|l|}
0.027 \\
$(0.007)^{* *}$ \\
\end{tabular} & $\begin{array}{l}0.028 \\
(0.007)^{* *}\end{array}$ & $\begin{array}{l}0.032 \\
(0.011)^{* *}\end{array}$ & $\begin{array}{l}0.029 \\
(0.006)^{* *}\end{array}$ & $\begin{array}{l}0.015 \\
(0.009) \\
\end{array}$ \\
\hline & \multicolumn{2}{|c|}{$\mathrm{N}=25383$} & \multicolumn{2}{|c|}{$\mathrm{N}=22667$} & \multicolumn{3}{|c|}{$\mathrm{N}=24235$} \\
\hline
\end{tabular}

Note: Six separate regressions were run to estimate each set of interactions (Math scores, own education, Parents' education interacted with leadership measures). Regressions also included controls for all other determinants of log earnings included in column (8) of Table 2. Each regression drops observations with missing information on variables of interest in that regression (own educational attainment, parents' education, and the leadership measures). 
Table 6: Effects of High School Leadership Activities on $\log ($ earnings) at different points after leaving high school: HSB Data

\begin{tabular}{|c|c|c|c|c|}
\hline & \multicolumn{4}{|c|}{ Earnings in year: } \\
\hline $\begin{array}{l}\text { High School } \\
\text { Leadership Measure } \\
\text { (1982): }\end{array}$ & 1988 & 1989 & 1990 & 1991 \\
\hline $\begin{array}{l}\text { Both Captain } \\
\text { and Leader }\end{array}$ & $\begin{array}{l}0.052 \\
(0.054)\end{array}$ & $\begin{array}{l}0.075 \\
(0.051)\end{array}$ & $\begin{array}{l}0.103 \\
(0.047)^{*}\end{array}$ & $\begin{array}{l}0.134 \\
(0.053)^{* *}\end{array}$ \\
\hline Captain only & $\begin{array}{l}0.083 \\
(0.043)^{*}\end{array}$ & $\begin{array}{l}0.065 \\
(0.043)\end{array}$ & $\begin{array}{l}0.061 \\
(0.040)\end{array}$ & $\begin{array}{l}0.074 \\
(0.045)\end{array}$ \\
\hline President only & $\begin{array}{l}0.061 \\
(0.037)\end{array}$ & $\begin{array}{l}0.091 \\
(0.036) * *\end{array}$ & $\begin{array}{l}0.082 \\
(0.036) *\end{array}$ & $\begin{array}{l}0.121 \\
(0.038) * * *\end{array}$ \\
\hline
\end{tabular}

Notes: Sample restricted to persons with reported earnings in all four years and who had not completed a graduate degree by 1992 . Robust standard errors in parentheses, clustered by individual.

Estimates are from a single regression pooling all four years of earnings data, $\mathrm{N}=7144$. Regression includes fixed effects for year and for each of the 636 high schools in the data, plus controls for participation in club/athletic activities, math score, parents' education, own education, and own education interacted with year. 
Table 7: Introducing Measures of Physical Appearance into Leadership Earnings Regressions.

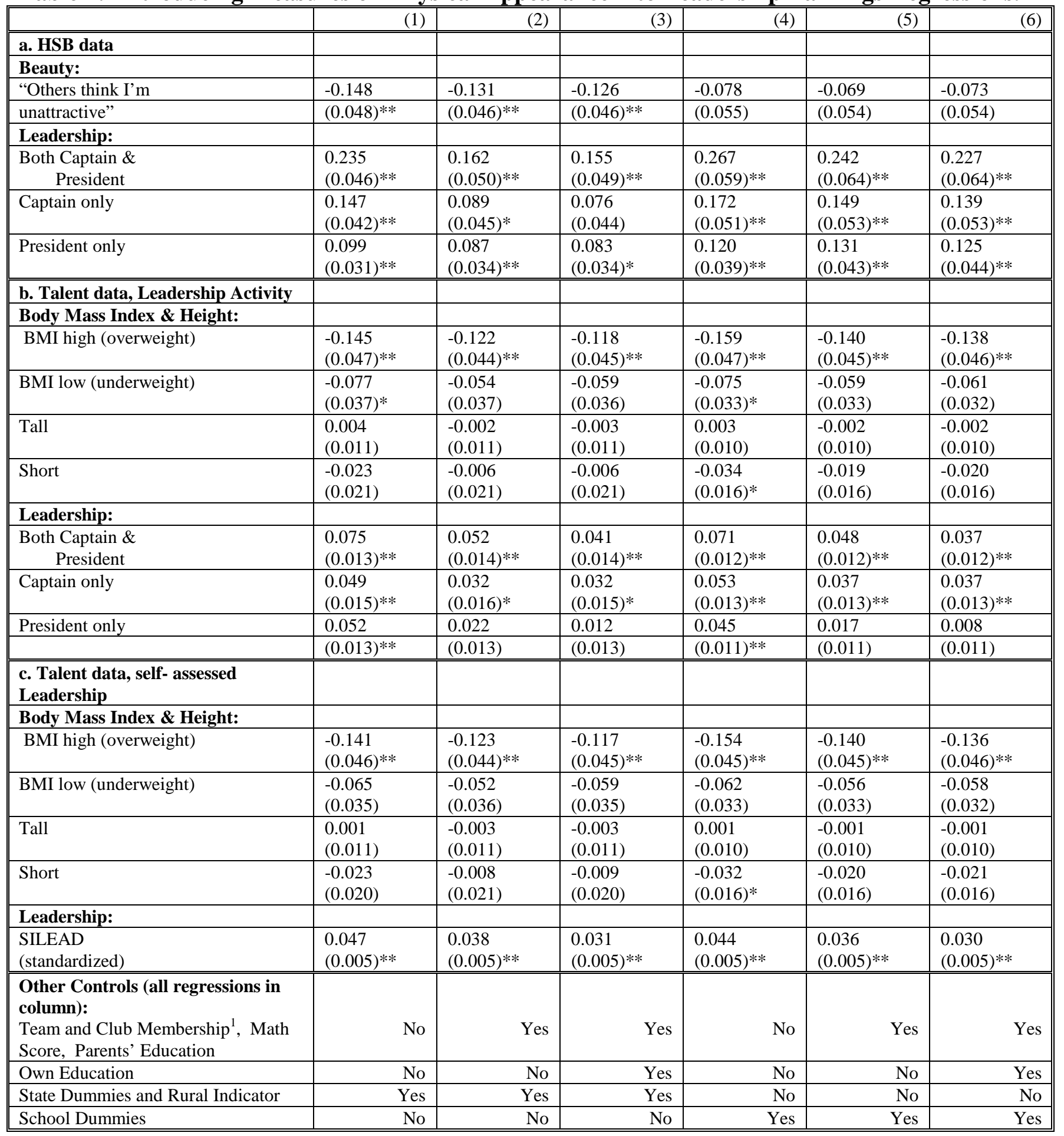

Notes: 1. Membership controls ot included in the regressions using self-assessed leadership.

Dependent variable: Log annual earnings in HSB; log hourly earnings in Talent. All Talent regressions included dummy variables for the grade attended in 1960. [overweight:bmi>31, underweight: bmi $<=17$, tall: $>=72$ ", short: $<=65$ "] 
Table 8: Effects of other psychological characteristics on the estimated returns to leadership

\begin{tabular}{|c|c|c|c|c|c|c|c|c|}
\hline & $(1)$ & $(2)$ & $\begin{array}{l}(3) \\
\end{array}$ & (4) & (5) & (6) & (7) & (8) \\
\hline \multicolumn{9}{|c|}{$\begin{array}{l}\text { Using Self-Assessed Leadership } \\
\text { (SILEAD) }\end{array}$} \\
\hline $\begin{array}{l}\text { Silead } \\
\text { (standardized) }\end{array}$ & $\begin{array}{l}0.037 \\
(0.004)^{* *}\end{array}$ & $\begin{array}{l}0.027 \\
(0.005)^{* *}\end{array}$ & $\begin{array}{l}0.030 \\
(0.005)^{* *}\end{array}$ & $\begin{array}{l}0.032 \\
(0.005)^{* *}\end{array}$ & $\begin{array}{l}0.033 \\
(0.005) * *\end{array}$ & $\begin{array}{l}0.034 \\
(0.005) * *\end{array}$ & $\begin{array}{l}0.024 \\
(0.005)^{* *}\end{array}$ & $\begin{array}{l}0.028 \\
(0.005) * *\end{array}$ \\
\hline $\begin{array}{l}\text { Enjoys } \\
\text { Socializing (Social) }\end{array}$ & & $\begin{array}{l}0.027 \\
(0.004)^{* *}\end{array}$ & & & & & $\begin{array}{l}0.022 \\
(0.005)^{* *}\end{array}$ & \\
\hline $\begin{array}{l}\text { Physically } \\
\text { Energetic (Vigor) }\end{array}$ & & & $\begin{array}{l}0.018 \\
(0.004) * *\end{array}$ & & & & $\begin{array}{l}0.008 \\
(0.005)\end{array}$ & $\begin{array}{l}0.015 \\
(0.005) * *\end{array}$ \\
\hline $\begin{array}{l}\text { Hardworking \& } \\
\text { Reliable (Mature) }\end{array}$ & & & & $\begin{array}{l}0.012 \\
(0.005)^{*}\end{array}$ & & & $\begin{array}{l}-0.002 \\
(0.006)\end{array}$ & $\begin{array}{l}-0.002 \\
(0.006)\end{array}$ \\
\hline $\begin{array}{l}\text { Self } \\
\text { Confident (Self) } \\
\end{array}$ & & & & & $\begin{array}{l}0.014 \\
(0.004) * *\end{array}$ & & $\begin{array}{l}0.007 \\
(0.004)\end{array}$ & $\begin{array}{l}0.011 \\
(0.004) *\end{array}$ \\
\hline $\begin{array}{l}\text { Neat and } \\
\text { Organized (Tidy) }\end{array}$ & & & & & & $\begin{array}{l}0.012 \\
(0.004)^{* *} \\
\end{array}$ & $\begin{array}{l}0.003 \\
(0.005) \\
\end{array}$ & $\begin{array}{l}0.006 \\
(0.005) \\
\end{array}$ \\
\hline \multicolumn{9}{|c|}{$\begin{array}{l}\text { Using Leadership } \\
\text { Activity: }\end{array}$} \\
\hline $\begin{array}{l}\text { Both Captain } \\
\text { and President }\end{array}$ & $\begin{array}{l}0.050 \\
(0.012)^{* *}\end{array}$ & $\begin{array}{l}0.038 \\
(0.012)^{* *}\end{array}$ & $\begin{array}{l}0.040 \\
(0.012)^{* *}\end{array}$ & $\begin{array}{l}0.041 \\
(0.012)^{* *}\end{array}$ & $\begin{array}{l}0.044 \\
(0.012)^{* *}\end{array}$ & $\begin{array}{l}0.044 \\
(0.012)^{* *}\end{array}$ & $\begin{array}{l}0.033 \\
(0.012)^{* *}\end{array}$ & $\begin{array}{l}0.036 \\
(0.012)^{* *}\end{array}$ \\
\hline Captain Only & $\begin{array}{l}0.036 \\
(0.013)^{* *}\end{array}$ & $\begin{array}{l}0.030 \\
(0.013)^{*}\end{array}$ & $\begin{array}{l}0.030 \\
(0.013)^{*}\end{array}$ & $\begin{array}{l}0.033 \\
(0.013) * *\end{array}$ & $\begin{array}{l}0.033 \\
(0.013) * *\end{array}$ & $\begin{array}{l}0.034 \\
(0.013) * *\end{array}$ & $\begin{array}{l}0.028 \\
(0.013)^{*}\end{array}$ & $\begin{array}{l}0.030 \\
(0.013) *\end{array}$ \\
\hline President Only & $\begin{array}{l}0.019 \\
(0.011)\end{array}$ & $\begin{array}{l}0.011 \\
(0.011)\end{array}$ & $\begin{array}{l}0.015 \\
(0.011)\end{array}$ & $\begin{array}{l}0.013 \\
(0.011)\end{array}$ & $\begin{array}{l}0.014 \\
(0.011)\end{array}$ & $\begin{array}{l}0.015 \\
(0.011)\end{array}$ & $\begin{array}{l}0.007 \\
(0.011)\end{array}$ & $\begin{array}{l}0.010 \\
(0.011)\end{array}$ \\
\hline Additional Controls: & None & Social & Vigor & Mature & Self & Tidy & All Five & All But Soc \\
\hline
\end{tabular}

Notes: All regressions include controls for math test score, parents' education, grade in 1960 indicators, school fixed effects. Captain/President regressions included controls for team and club participation. Sample sizes 24030 with leadership activities, and 27413 without. All psychological measures are standardized to have mean zero, standard deviation 1 within grade cohorts. 
Table 9: Linear Probability Model Coefficients for Selection into "Managerial" Occupations, Talent Data

\begin{tabular}{|l|l|}
\hline & \multicolumn{1}{|c|}{ Coefficient } \\
\hline Leadership Activity: & \multicolumn{1}{|c|}{ (std. error) } \\
\hline Both Captain \& President & .036 \\
& $(.011)^{* *}$ \\
\hline Captain only & .036 \\
& $(.013)^{* *}$ \\
\hline President only & .036 \\
& $(.010)^{* *}$ \\
\hline & \\
\hline Self-Assessed Leadership & 0.023 \\
(continuous) & $(0.004)^{* *}$ \\
\hline & \\
\hline Self-Assessed Leadership & \\
(categorical): & \\
\hline Silead $=5$ & 0.063 \\
(top 3\%) & $(0.020)^{* *}$ \\
\hline $\begin{array}{l}\text { Silead }=4 \\
\left(90^{\text {th }}-97^{\text {th }} \text { percentile) }\right.\end{array}$ & 0.057 \\
\hline Silead $=3$ & $(0.018)^{* *}$ \\
$\left(81^{\text {st }}-90^{\text {th }}\right.$ percentile $)$ & 0.053 \\
\hline Silead $=2$ & $(0.014)^{* *}$ \\
\hline$\left(65^{\text {th }}-81^{\text {st }}\right.$ percentile) $)$ & 0.057 \\
\hline Silead $=1$ & $(0.011)^{* *}$ \\
\hline$\left(38^{\text {th }}-65^{\text {th }}\right.$ percentile) & 0.008 \\
\hline & $(0.008)$ \\
\hline
\end{tabular}

Robust standard errors in parentheses

* significant at $5 \%$ level; ** significant at $1 \%$ level

Other controls included in all regressions: math test score, parents' education, own education, grade in 1960 indicators, school fixed effects. Captain/President regressions included controls for team and club participation. Sample sizes 24939 with leadership activities, and 28425 with Silead. 
Table 10: Introducing Occupation Controls into Leadership Wage Regressions: Talent Data.

\begin{tabular}{|c|c|c|c|c|c|c|}
\hline & (1) & (2) & (3) & (4) & (5) & (6) \\
\hline \multicolumn{7}{|l|}{ a. Leadership Activity } \\
\hline Both Captain and President & $\begin{array}{l}0.055 \\
(0.014) * *\end{array}$ & $\begin{array}{l}0.048 \\
(0.011) * *\end{array}$ & $\begin{array}{l}.046 \\
(.012) * *\end{array}$ & $\begin{array}{l}0.042 \\
(0.014) * *\end{array}$ & $\begin{array}{l}0.043 \\
(0.011) * *\end{array}$ & $\begin{array}{l}0.042 \\
(.012)^{* *}\end{array}$ \\
\hline Captain Only & $\begin{array}{l}0.029 \\
(0.015) \\
\end{array}$ & $\begin{array}{l}0.028 \\
(0.013)^{*}\end{array}$ & $\begin{array}{l}.013 \\
(.014) \\
\end{array}$ & $\begin{array}{l}0.028 \\
(0.015) \\
\end{array}$ & $\begin{array}{l}0.027 \\
(0.013) *\end{array}$ & $\begin{array}{l}0.013 \\
(0.013) \\
\end{array}$ \\
\hline President Only & $\begin{array}{l}0.023 \\
(0.013) \\
\end{array}$ & $\begin{array}{l}0.022 \\
(0.010)^{*} \\
\end{array}$ & $\begin{array}{l}.013 \\
(.011) \\
\end{array}$ & $\begin{array}{l}0.013 \\
(0.012) \\
\end{array}$ & $\begin{array}{l}0.018 \\
(0.010) \\
\end{array}$ & $\begin{array}{l}0.010 \\
(0.011) \\
\end{array}$ \\
\hline $\begin{array}{l}\text { "Both" x } \\
\text { Managerial Occupation }\end{array}$ & & & $\begin{array}{l}.030 \\
(.033)\end{array}$ & & & $\begin{array}{l}0.027 \\
(0.032)\end{array}$ \\
\hline $\begin{array}{l}\text { Captain Only } \mathrm{x} \\
\text { Managerial Occupation }\end{array}$ & & & $\begin{array}{l}.102 \\
(.036)^{* *}\end{array}$ & & & $\begin{array}{l}0.103 \\
(0.035) * *\end{array}$ \\
\hline $\begin{array}{l}\text { President Only x } \\
\text { Managerial Occupation }\end{array}$ & & & $\begin{array}{l}.059 \\
(.030)^{*} \\
\end{array}$ & & & $\begin{array}{l}0.055 \\
(0.029) \\
\end{array}$ \\
\hline \multicolumn{7}{|l|}{$\begin{array}{l}\text { b. Self-Assessed } \\
\text { Leadership }\end{array}$} \\
\hline SILEAD (standardized) & $\begin{array}{l}0.038 \\
(0.005)^{* *}\end{array}$ & $\begin{array}{l}0.030 \\
(0.004)^{* *}\end{array}$ & $\begin{array}{l}.023 \\
(.005)^{* *}\end{array}$ & $\begin{array}{l}0.031 \\
(0.005)^{* *}\end{array}$ & $\begin{array}{l}0.028 \\
(0.004)^{* *}\end{array}$ & $\begin{array}{l}0.021 \\
(0.005)^{* *}\end{array}$ \\
\hline $\begin{array}{l}\text { SILEAD x } \\
\text { Managerial Occupation }\end{array}$ & & & $\begin{array}{l}.040 \\
(.012)^{* *}\end{array}$ & & & $\begin{array}{l}0.038 \\
(0.012) * * \\
\end{array}$ \\
\hline Own Education controls & No & No & No & Yes & Yes & Yes \\
\hline $\begin{array}{l}\text { Occupation controls } \\
\text { (694 categories) }\end{array}$ & No & Yes & Yes & No & Yes & Yes \\
\hline
\end{tabular}

Robust standard errors in parentheses

* significant at 5\% level; ** significant at $1 \%$ level

Sample size: 23980 for all regressions

Controls included in all regressions: math score, parents' education, grade in 1960, $\log ($ state average wages). Controls for team and club membership included in all leadership activity regressions. Silead standardized to mean 0 , sd 1 within grade cohort

Dependent Variable: log of hourly wage 11 years after high school. 
Table 11: Instrumental Variables and Maximum Likelihood Estimates of the Return to High School Leadership Activities: Project Talent data.

\begin{tabular}{|c|c|c|c|c|c|c|c|c|c|}
\hline & $(1)$ & $(2)$ & (3) & $(4)$ & $(5)$ & $(6)$ & (7) & $(8)$ & (9) \\
\hline Estimation Method & OLS & IV & ML & OLS & IV & ML & OLS & IV & ML \\
\hline \multicolumn{10}{|l|}{ Leadership Activity: } \\
\hline $\begin{array}{l}\text { Both Captain } \\
\text { and President }\end{array}$ & $\begin{array}{r}0.052 \\
(0.013)^{* *}\end{array}$ & $\begin{array}{r}0.179 \\
(0.073)^{*}\end{array}$ & $\begin{array}{r}.141 \\
(.045)^{* * *}\end{array}$ & $\begin{array}{r}0.052 \\
(0.013)^{* *}\end{array}$ & $\begin{array}{r}0.180 \\
(0.073)^{*}\end{array}$ & $\begin{array}{r}.143 \\
(.046)^{* *}\end{array}$ & $\begin{array}{r}0.049 \\
(0.013)^{* *}\end{array}$ & $\begin{array}{r}0.161 \\
(0.073)^{*}\end{array}$ & $\begin{array}{r}.133 \\
(.047)^{* *}\end{array}$ \\
\hline \multicolumn{10}{|l|}{ Cognitive Scores: } \\
\hline Own Math Score & $\begin{array}{r}0.215 \\
(0.019)^{* *} \\
\end{array}$ & $\begin{array}{r}0.212 \\
(0.019)^{* *} \\
\end{array}$ & $\begin{array}{r}.213 \\
(.019) * * \\
\end{array}$ & $\begin{array}{r}0.216 \\
(0.019)^{* *} \\
\end{array}$ & $\begin{array}{r}0.213 \\
(0.020)^{* *} \\
\end{array}$ & $\begin{array}{r}.213 \\
(.019)^{* *} \\
\end{array}$ & $\begin{array}{r}0.216 \\
(0.019)^{* *} \\
\end{array}$ & $\begin{array}{r}0.214 \\
(0.020)^{* *} \\
\end{array}$ & $\begin{array}{r}.214 \\
(.019)^{* *} \\
\end{array}$ \\
\hline \multicolumn{10}{|l|}{ School Characteristics: } \\
\hline $\begin{array}{r}\text { Schoolwide Mean } \\
\text { Math Scores }\end{array}$ & & & & $\begin{aligned}-0.020 \\
(0.053)\end{aligned}$ & $\begin{array}{l}-0.013 \\
(0.054)\end{array}$ & $\begin{array}{r}-.015 \\
(.053)\end{array}$ & $\begin{array}{r}-0.196 \\
(0.066)^{* *}\end{array}$ & $\begin{array}{r}-0.177 \\
(0.068)^{* *}\end{array}$ & $\begin{array}{r}-.182 \\
(.067)^{* * *}\end{array}$ \\
\hline $\begin{array}{r}\text { Mean Math Gain (Grade } 12 \text { Mean } \\
\text { Minus Grade } 10 \text { Mean) }\end{array}$ & & & & $\begin{array}{r}0.070 \\
(0.052)\end{array}$ & $\begin{array}{r}0.059 \\
(0.052)\end{array}$ & $\begin{array}{r}.062 \\
(.052)\end{array}$ & $\begin{array}{r}0.056 \\
(0.052)\end{array}$ & $\begin{array}{r}0.047 \\
(0.052)\end{array}$ & $\begin{array}{r}.049 \\
(.052)\end{array}$ \\
\hline $\begin{array}{r}\text { Proportion with } \\
\text { Family Income }>\$ 9 \mathrm{~K}\end{array}$ & & & & & & & $\begin{array}{r}0.014 \\
(0.070)\end{array}$ & $\begin{array}{r}-0.001 \\
(0.071)\end{array}$ & $\begin{array}{r}.002 \\
(.070)\end{array}$ \\
\hline $\begin{array}{r}\text { Proportion with } \\
\text { Family Income }<\$ 6 \mathrm{~K} \\
\end{array}$ & & & & & & & $\begin{array}{r}-0.207 \\
(0.069)^{* *} \\
\end{array}$ & $\begin{array}{r}-0.206 \\
(0.069) * * \\
\end{array}$ & $\begin{array}{r}-.206 \\
(.069)^{* * *} \\
\end{array}$ \\
\hline Observations & 21188 & 21188 & 21188 & 21188 & 21188 & 21188 & 21188 & 21188 & 21188 \\
\hline R-squared/log likelihood & 0.08 & 0.06 & -7209285.7 & 0.08 & 0.06 & -7204656.3 & 0.08 & 0.07 & -7167239.9 \\
\hline Error correlation $(\rho)$ & & & $\begin{array}{r}-.136 \\
(.066)^{*}\end{array}$ & & & $\begin{array}{r}-.140 \\
(.067)^{*}\end{array}$ & & & $\begin{array}{c}-.129 \\
(.067)\end{array}$ \\
\hline
\end{tabular}

Robust standard errors in parentheses. * significant at 5\% level; ** significant at $1 \%$ level

Controls included in all regressions: parent education, grade cohort, rural, log of statewide mean hourly earnings.

Columns (7)-(9) also include controls for father's occupation and father's leadership roles.

IV and ML use schoolwide mean of "both captain and president" as an instrument for leadership activity.

Sample: $10^{\text {th }}-12^{\text {th }}$ graders (white men), in schools with at least 20 observations for schoolwide means. 
Figure 1: Estimated effect of self-assessed leadership skill in high school on $\log$ (wages) eleven years later, Project TALENT Data.

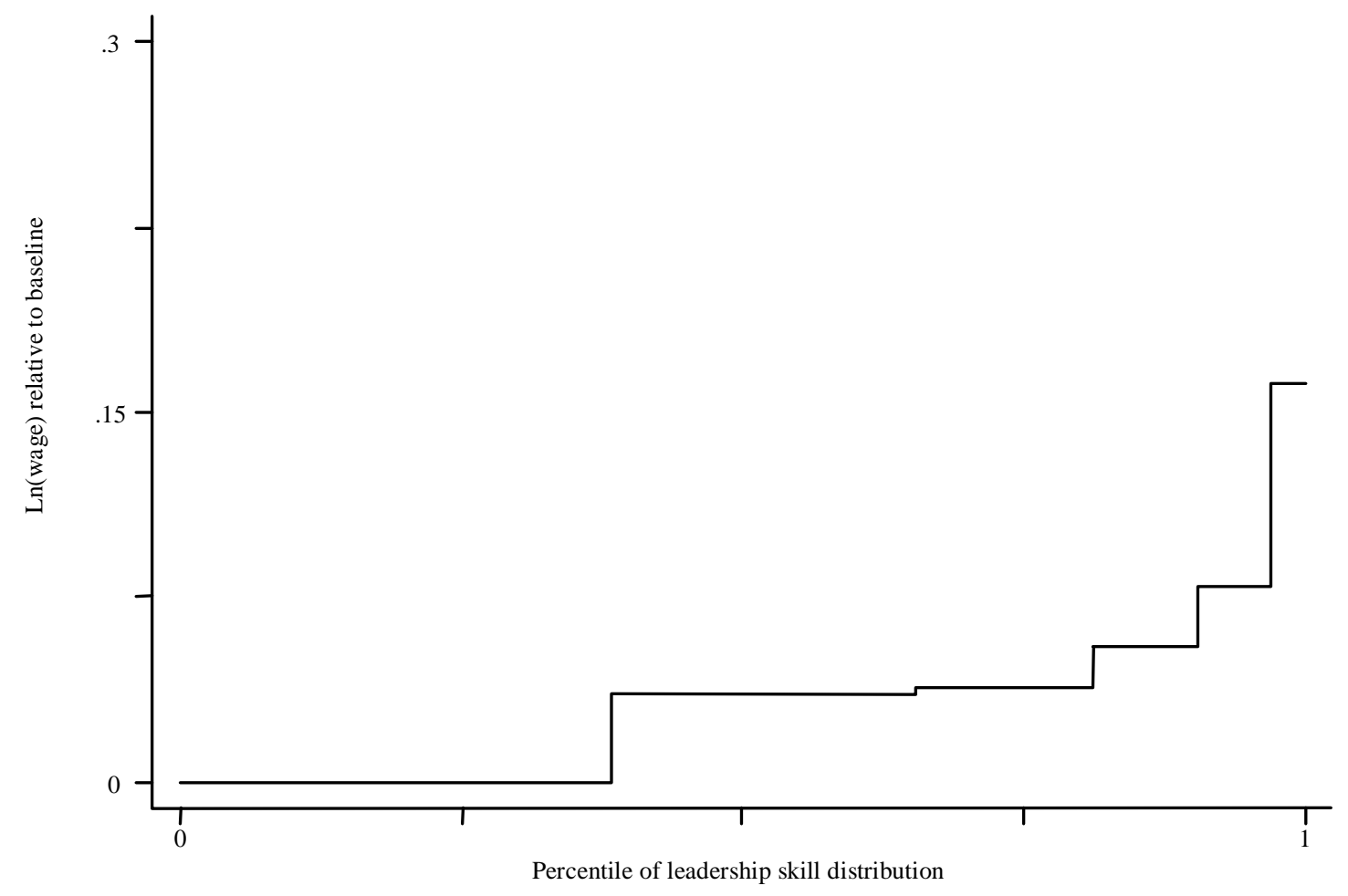

Figure 2: Estimated effect of number of different leadership experiences in high school on $\log ($ annual earnings) nine years later, High School and Beyond Data

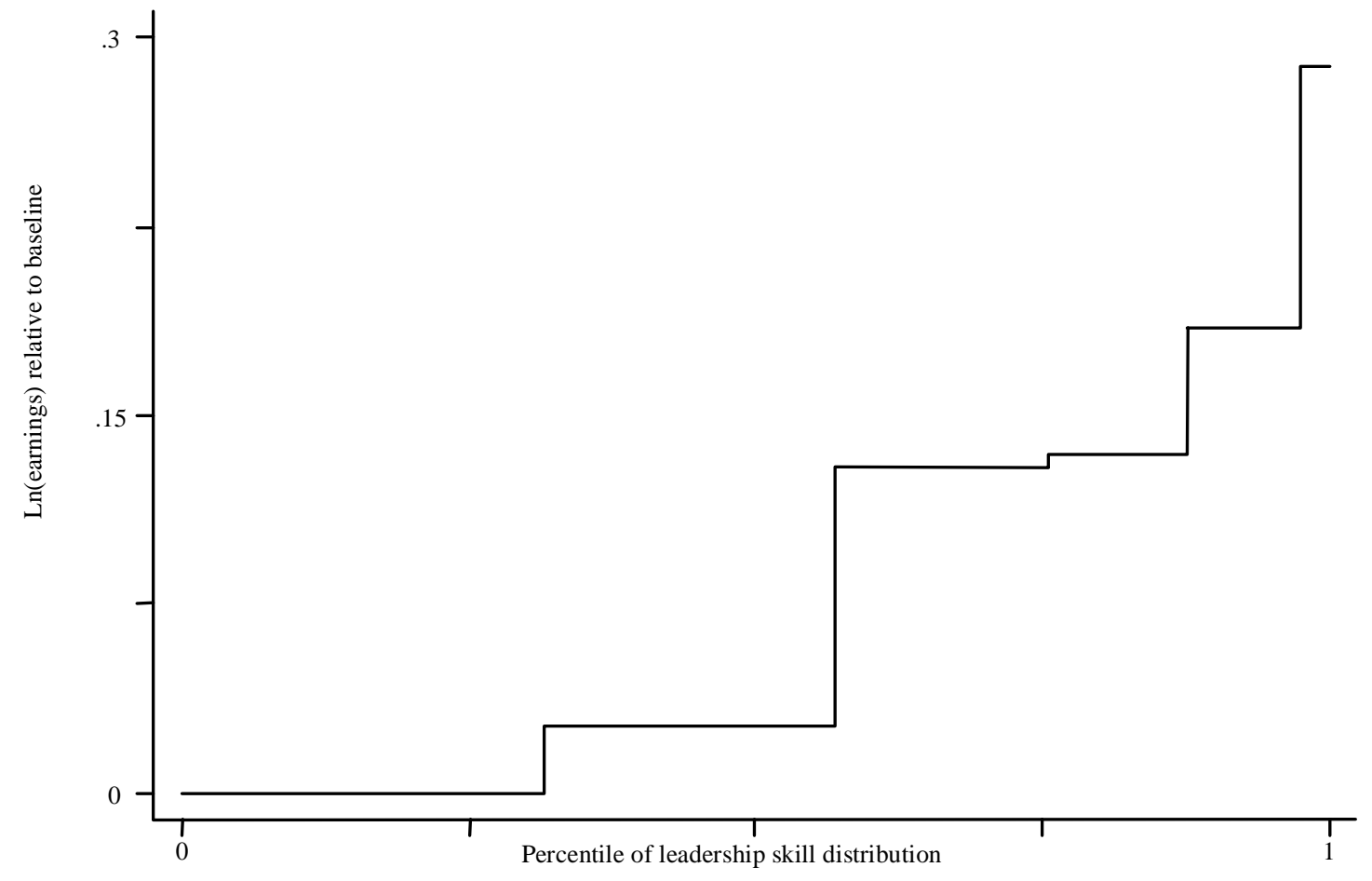




\section{IZA Discussion Papers}

$\begin{array}{cl}\text { No. } & \text { Author(s) } \\ 466 & \begin{array}{l}\text { J. E. Askilds } \\ \text { E. Bratberg } \\ \text { Ø. A. Nilsen }\end{array} \\ 467 & \begin{array}{l}\text { A. Venturini } \\ \text { C. Villosio }\end{array} \\ 468 & \text { J. Wagner }\end{array}$

R. Lalive

J. C. van Ours

J. Zweimüller
A. Cigno
F. C. Rosati
L. Guarcello
B. R. Chiswick
Y. Liang Lee
P. W. Miller

\section{R. Foellmi \\ J. Zweimüller}

J. C. van Ours

J. T. Addison

L. Bellmann

A. Kölling

\section{Z. Hercowitz}

E. Yashiv

W. A. Cornelius

T. Tsuda

\section{A. Clark}

D. A. Jaeger

H. Gersbach

A. Schniewind
J. T. Addison

C. R. Belfield

G. Saint-Paul

E. Schlicht

P. Kuhn

C. Weinberger
Title

Area

Date

Unemployment, Labour Force Composition and 1

Sickness Absence: A Panel Data Study

$04 / 02$

Are Immigrants Competing with Natives in the 1

$04 / 02$

Italian Labour Market? The Employment Effect

The Impact of Risk Aversion, Role Models, and

$04 / 02$

the Regional Milieu on the Transition from

Unemployment to Self-Employment: Empirical

Evidence for Germany

The Effect of Benefit Sanctions on the Duration of Unemployment

Does Globalisation Increase Child Labour?

Immigrants' Language Skills and Visa Category

$04 / 02$

Structural Change and the Kaldor Facts of

3

04/02

\section{Economic Growth}

A pint a day raises a man's pay, but smoking

5

04/02 blows that gain away

Unions, Works Councils and Plant Closings in

04/02 Germany

$$
\text { Immigration }
$$

Labor Market Incorporation of Immigrants in Analysis

Natives, the Foreign-Born and High School the GED

Uneven Technical Progress and Unemployment 3

Unions and Employment Growth: The One

\section{Constant?}

The Complexity of Economic Policy:

04/02

I. Restricted Local Optima in Tax Policy Design

Hiring Standards and Market Clearing

04/02

Leadership Skills and Wages

04/02

An updated list of IZA Discussion Papers is available on the center's homepage www.iza.org. 